\title{
Evidence for parapatric speciation in the Mormyrid fish, Pollimyrus castelnaui (Boulenger, 1911), from the Okavango-Upper Zambezi River Systems: P. marianne sp. nov., defined by electric organ discharges, morphology and genetics
}

\author{
Bernd Kramer ${ }^{\mathrm{a}}$, Herman van der Bank ${ }^{\mathrm{b}}$, Nicolette Flint ${ }^{\mathrm{b}}$, Hedi Sauer-Gürth ${ }^{\mathrm{c}} \&$ Michael Wink $^{\mathrm{c}}$ \\ ${ }^{a}$ Zoologisches Institut, Universität Regensburg, D-93040 Regensburg, Germany \\ (e-mail: bernd.kramer@biologie.uni-regensburg.de) \\ ${ }^{\mathrm{b}}$ Zoology Department, Rand Afrikaans University, P.O. Box 524, Auckland Park, 2006, South Africa \\ ${ }^{\mathrm{c}}$ Institut für Pharmazie und Molekulare Biotechnologie, Universität Heidelberg, D-69120 Heidelberg, Germany
}

Received 5 December $2001 \quad$ Accepted 16 January 2003

Key words: allozymes, mitochondrial DNA, behaviour, cytochrome $b$, sequence analysis, clinal variation, phylogeny, phylogeography, Caprivi Strip

\section{Synopsis}

We report on parapatric speciation in the mormyrid fish, Pollimyrus castelnaui (Boulenger, 1911), from the Okavango and the Upper Zambezi River systems. We recognise samples from the Zambezi River as a distinct species, P. marianne, displaying an eastern phenotype of electric organ discharge (EOD) waveform (Type 3) that is distinct from the western EOD phenotype (Type 1) observed in P. castelnaui samples from the neighbouring Okavango. Samples from the geographically intermediate Kwando/Linyanti River (a tributary of the Zambezi that is also intermittently connected to the Okavango) presented a more variable third EOD phenotype (Type 2). In 13 out of 14 morphological characters studied, the Zambezi River samples differed significantly from $P$. castelnaui. Morphologically and in EOD characters, the Kwando/Linyanti fish are distinct from both $P$. castelnaui and P. marianne. Sequence analysis of the mitochondrial cytochrome $b$ gene unambiguously reveals that specimens from the Zambezi River System form a well supported taxon which clearly differs from P. castelnaui from the Okavango (1.5-2.5\% sequence divergence). Within specimens from the Kwando-Zambezi System some geographic differentiation can be detected (nucleotide substitutions up to $0.6 \%$ ); but groups cannot be resolved with certainty. Significant allozyme differences were found between the Okavango and all other EOD types from the Upper Zambezi System, and, within the Zambezi System, between the Kwando (Type 2) and Zambezi (Type 3) individuals. The low Wright's fixation index values, the lack of fixed allele differences, and small genetic distances provide little evidence for speciation between groups within the Zambezi System, but moderate to great fixation index values and significant allele frequency differences were observed between the Okavango and the other fishes. It is concluded that within the Zambezi System, differentiation between Kwando/Linyanti and Zambezi populations (as revealed by morphology and EOD waveform comparisons) is so recent that substantial genetic (allozyme and mitochondrial sequence) differences could not have evolved, or were not detected.

\section{Introduction}

The weakly electric elephantfish or snoutfish (Mormyridae, Teleostei) are Africa's largest endemic family of freshwater fishes (about 200 species) with the equatorial Congo (Zaire) River system holding most species (about 75; Gosse 1984). The southern Zambezi Region holds far fewer fish species and only about ten mormyrids (Bell-Cross \& Minshull 1988, Skelton 2001), six of which occur in our study region, the 
Upper Zambezi/Okavango that forms a sporadically interconnected system (Skelton et al. 1985).

Except for systematics, and check-lists of fishes for restricted areas, the mormyrids of the Zambezi Region are poorly studied, particularly regarding behaviour and physiology. Only very recently have the speciescharacteristic waveforms of most species' electric organ discharges (EODs) become known from field studies for the Upper Zambezi River (Namibia) and north-eastern South Africa (Kramer 1996). Their phylogenetic relationships were studied using molecular genetics (Van der Bank \& Kramer 1996). Withinand between-population variability has been assessed genetically (Van der Bank \& Van der Bank 1995, Van der Bank 1996), as well as morphologically and for EODs in two species (Kramer 1997a,b).

The representatives of the family Mormyridae are defined mainly by skeletal characters at present (Taverne 1971). The genus Pollimyrus (Taverne 1971) contains 19 species, which are distributed throughout tropical Africa, but with only one species, Pollimyrus castelnaui, occurring in southern Africa (Figure 1). The dwarf stonebasher, as it is commonly known, is found in the Cunene, Okavango, Upper Zambezi and Kafue Rivers. It has also been observed in the northern areas of Lake Malawi (Skelton 2001). Pollimyrus castelnaui inhabits the dense marginal vegetation of both rivers and floodplain lagoons, and its biology is virtually unknown.

Mormyrids are both electrogenic and electroreceptive (Lissmann 1958, Szabo 1974, Szabo \& Fessard 1974, Turner et al. 1999). Their EODs are involved in social contact, territorial behaviour, prey detection, courtship, and individual recognition (for reviews, see Kramer 1990, 1996, Moller 1995). The EOD waveform is stereotyped and reflects the species-specific anatomy and physiology of the electric organ (Bennett 1971, Bass 1986); P. adspersus discriminates between playback of conspecific versus heterospecific EOD waveforms (Graff \& Kramer 1992). EODs are a mating signal (Bratton \& Kramer 1989, Crawford 1991), and fish even detect the small waveform differences observed among conspecific EODs (Graff \& Kramer 1992, Paintner 1998, Paintner \& Kramer in preparation). Mating signals play an important role in some current species concepts (Turner 1999). In our previous studies EOD waveform differences greatly assisted in resolving systematic questions (e.g., Kramer \& Van der Bank 2000, Kramer et al. in press).

For the present study, we examined local populations traditionally determined as $P$. castelnaui originating from the Kwando/Zambezi System and from the Okavango for differences in EOD, morphology and molecular genetics. For centuries morphology has been, and continues to be, the prime source of data sets upon which systematical decisions are based. Recently, the discriminative power has much increased due to the use of new multivariate statistical analyses. Phylogenetic studies using molecular genetic data sets have successfully been used in a wide variety of organisms, from bacteria to Neanderthals (e.g., Kocher \& Stepien 1997 for fishes; for mormyrids, Alves-Gomes \& Hopkins 1997, Lavoué et al. 2000, Sullivan et al. 2000). We have analysed allozyme patterns and nucleotide sequences of the mitochondrial cytochrome $b$ gene to infer phylogenetic and phylogeographic relationships in the $P$. castelnaui complex.

\section{Materials and methods}

\section{Fish studied}

Specimens examined were initially identified as P. castelnaui (Boulenger, 1911) using dichotomous keys in Bell-Cross \& Minshull (1988) and Skelton (2001), which are considered effective for fish populations occurring in Caprivi (Namibia) and the Okavango Delta (Botswana). Abbreviations used to represent institutions and collections cited follow Leviton et al. (1985).

The first indication of $P$. castelnaui's presence in the Upper Zambezi was perhaps that by Jubb (1958), confirmed by Van der Waal \& Skelton (1984). Van der Waal \& Skelton (1984) collected from many sites of the short Namibian stretch of the Upper Zambezi (that is, between Katima Mulilo and the Zimbabwean border), as well as from the Kwando River, Linyanti Swamps and Chobe River. In the neighbouring, sporadically interconnected Okavango System the presence of $P$. castelnaui was re-confirmed by more recent collections (Skelton et al. 1985).

\section{Geography}

The Kwando and Zambezi Rivers are separated by approximately $110 \mathrm{~km}$, but only by $60 \mathrm{~km}$ near Linyanti (Figure 2). The river systems were linked for seven brief periods of time since 1942 when the Zambezi River overflowed its banks near Linyanti, with the last occasion as recent as 1978 (no data available before 1942). In 1942, a small quantity of water was collected in 




Figure 1. Photographs of samples of the Pollimyrus complex. T, one of the two P. castelnaui type specimens; K, a specimen from the Kwando River; L, from Linyanti Swamp; Z, P. marianne from the Zambezi River. 


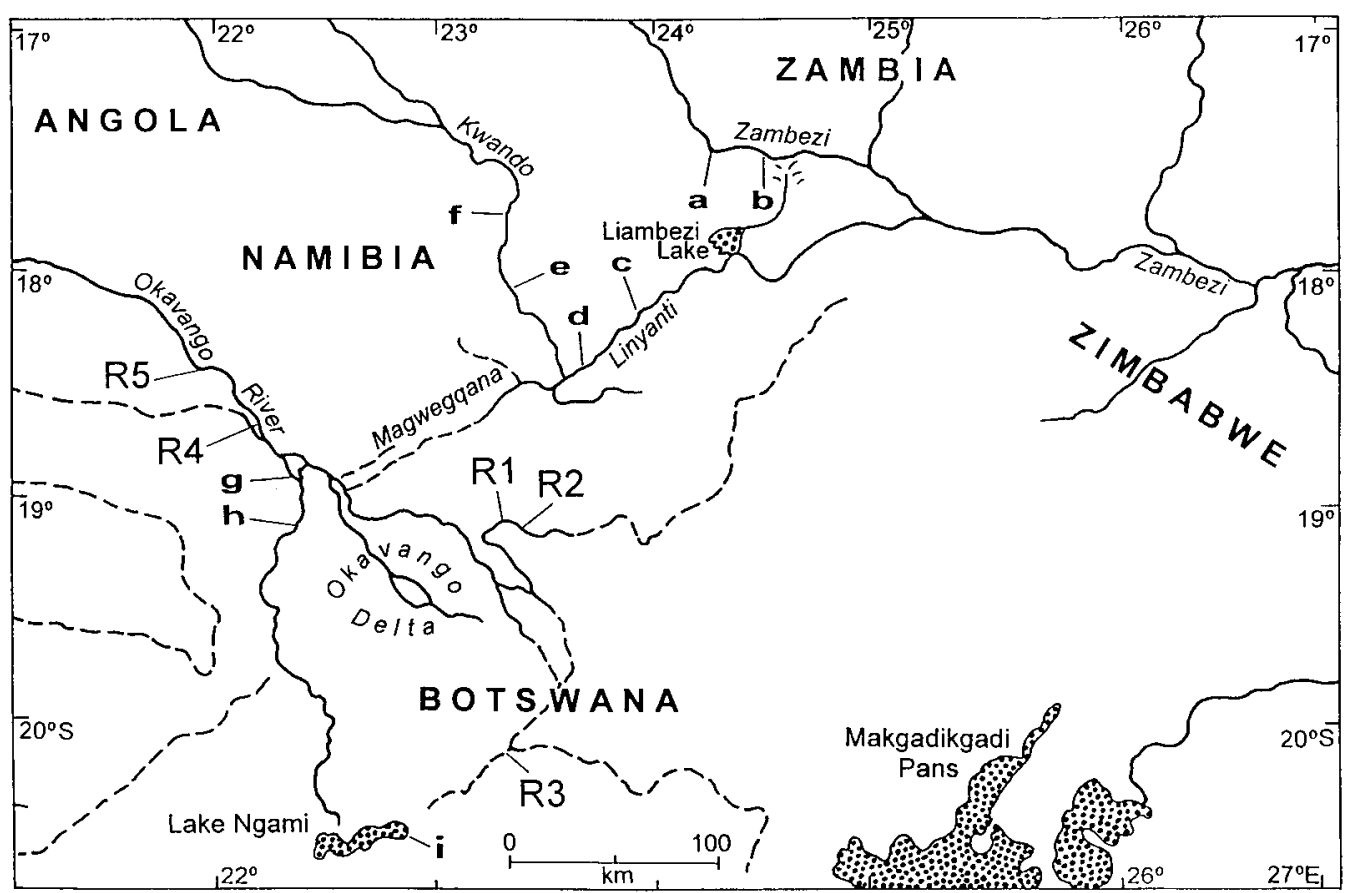

Figure 2. Sampling sites (a-f) in Caprivi and the neighbouring Okavango River (g,h) shown with its Delta. The historical type locality for P. castelnaui, 'Ngami Lake' (i), is shown as given but the Okavango River has been identified by later work. R1-R5, sampling sites for more recent SAIAB museum material. a, Katima Mulilo; b, Lisikili; c, Sampis; d, Nkasa Island; e, Nakatwa, Buffalo Camp; f, Kongola.

Liambezi Lake (connecting the Chobe that is draining into the Zambezi with Linyanti) after the Zambezi River overflowed its banks (Grobler 1987) and in 1948 the Zambezi River overflowed its banks again. The next floods were in 1952, 1958 (Schlettwein 1985a), 1968, 1969 (Schlettwein 1985b), and again in 1975 (Van der Waal 1978), and 1978. Lake Liambezi dried up completely in 1985, and in September-October 2001 it again held some water $(28 \%$ full by water from the Zambezi, through Chobe; Herman van der Bank, pers. comm.) The Kwando River is also directly, though only sporadically, linked to the Okavango System on its western side by the Magwegqana channel or 'Selinda Spillway' (Skelton et al. 1985).

\section{Electric organ discharges: recording and analysis}

In contrast to EOD waveform, the EOD rate of a mormyrid is highly variable, depending on the ever-fluctuating behavioural and ecological context. Temperature affects EOD pulse duration only weakly (Kramer \& Westby 1985). A drastic step change in water conductivity, however, affects EOD waveform and duration strongly; within 1-2 days waveform recovers because the electric organ is capable of active impedance matching (Kramer \& Kuhn 1993). For a given individual, there is long-term stability of its EOD waveform over days, weeks and months (Bratton \& Kramer 1988). The electric organ clearly is set for stability of its output, the waveform and duration of an EOD pulse, in a variable environment.

EODs of each fish were recorded in the field immediately after capture, in a 37-1 plastic aquarium filled with river water where the fish was collected. Conductivity changes possibly affecting EOD in the short term were excluded (Kramer \& Kuhn 1993).

Temperature $\left( \pm 0.1^{\circ} \mathrm{C}\right)$ and water conductivity $\left( \pm 1 \mu \mathrm{S} \mathrm{cm}^{-1}\right)$ were constantly monitored using an electronic meter (LF92 by WTW, Germany). Fish were placed between a pair of carbon rod electrodes that was connected to a differential amplifier with a variable gain (up to $\times 10 ; 0.2 \mathrm{~Hz}-100 \mathrm{kHz}$; filter slopes, $-3 \mathrm{~dB}$ per octave; electronics workshop, Biology Department, University of Regensburg). Amplifier output was recorded by a digital storage oscilloscope (up to $10 \mathrm{MHz}$ conversion rate; amplitude resolution, 8 bit; 512 points per trace), and data were numerically transferred onto the hard disk of a computer via digital 
interface. Usually 8 traces per fish were recorded. Equipment was battery operated.

We used custom-designed computer programs for analysis of EOD waveforms (programmed using a software package for signal analysis, Famos v3.2). When necessary, EOD duration was corrected for $25^{\circ} \mathrm{C}$ using a $\mathrm{Q}_{10}$ value of 1.5 (Kramer \& Westby 1985) before data analysis. EOD duration was determined in waveforms smoothed by $4 \times$ averaging, as the interval from the definitive rise of the first phase above baseline to where the last phase ended by crossing zero.

Subsequent to EOD recording we killed fish by an overdose of anaesthetic (2-phenoxy-ethanol), measured their standard length using vernier calipers, and fixed them in 10\% formalin for morphological studies. Statistical analyses were carried out as indicated in Results; P-values are two-tailed unless otherwise stated.

\section{Anatomy}

We made measurements used to establish morphometrics as shown in Figure 3 using vernier caliper readings to $0.1 \mathrm{~mm}$. Abbreviations of measurements were as follows: PDL, predorsal length: distance tip of snout to dorsal fin origin. PAL, distance tip of snout to anal fin origin. LD, dorsal fin length. LA, anal fin length. pD, distance dorsal fin origin to end of caudal peduncle. CPL, length of caudal peduncle (end of anal fin base to midbase caudal fin). CPD, depth of caudal peduncle: the least vertical distance across the caudal peduncle. LS, length of snout: distance tip of snout to posterior orbital rim of eye. HL, head length: distance tip of the snout to furthest bony edge of the operculum. $\mathrm{Na}$, distance between the pair of nares of one side (from centre to centre). SL, standard length: distance tip of snout to midbase caudal fin. BD, body depth: the greatest vertical distance across the body. $\mathrm{nD}$, number of dorsal fin rays. nA, number of anal fin rays. SPc, number of scales around caudal peduncle.

\section{Allozyme study}

We stored fish samples in liquid nitrogen and transported them to the laboratory. We analysed tissue extracts by horizontal starch gel electrophoresis $(12 \%$ gels), following the procedures, nomenclature and buffer systems in Van der Bank \& Kramer (1996). We analysed the allozyme data with BIOSYS-2 statistical software (Swofford et al. 1997).

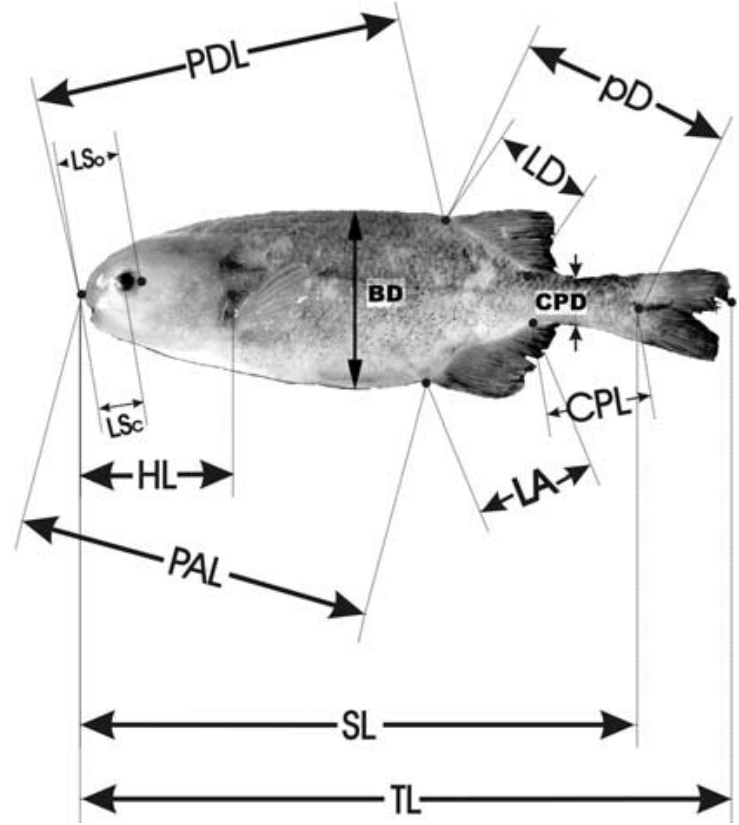

Figure 3. Morphometrics taken on samples of the Pollimyrus complex. PDL, predorsal length. PAL, preanal length. LD, dorsal fin length. LA, anal fin length. $\mathrm{pD}$, peduncle-to-dorsalis length. CPL, caudal peduncle length. CPD, caudal peduncle depth. LS, length of snout (measured in two different ways, $\mathrm{LS}_{\mathrm{c}}$ and $\mathrm{LS}_{\mathrm{o}}$ ). HL, head length. SL, standard length. BD, body depth.

\section{DNA study}

\section{DNA-isolation}

We isolated DNA from muscle tissue which was preserved in ethanol using the 'proteinase K method' as described earlier (Heidrich et al. 1995).

\section{PCR and DNA-Sequencing}

Primer pairs used for PCR (modified from Kocher et al. 1989; Pääbo 1990) were L-14841 (5'-CCA TCC AAC ATC TCA GCA TGA TGA AA-3')[positions refer to the cytochrome $b$ gene of Gallus; Desjardins \& Morais 1990]: and mt-F (H-15917; 5'-TAG TTG GCC AAT GAT GAT GAA TGG GTG TTC TAC TGG TT-3'): or L-14724 (5'-CGA AGC TTG ATA TGA AAA ACC ATC GT TG-3') and Mt-E (H15713; 5'-AAT AGG AAG TAT CAT TCG GGT TTG T-3'). For amplification $0.5 \mu \mathrm{g}$ of total DNA was used as a template, plus 20 pmol each of the two corresponding PCR primers, $1.5 \mathrm{mM} \mathrm{MgCl} 2,0.1 \mathrm{mM}$ of each dNTPs, $5 \mu 110 \times$ amplification buffer $(100 \mathrm{mM}$ Tris- $\mathrm{HCl}, \mathrm{pH} 8.5,500 \mathrm{mM} \mathrm{KCl}, 5 \%$ Triton X-100) 
and 0.5 units Taq-Polymerase (Pharmacia, Freiburg) in a total volume of $50 \mu \mathrm{l}$. After an initial denaturation ( 4 min at $94^{\circ} \mathrm{C}$ ), 30 cycles of $45 \mathrm{~s}$ at $94^{\circ} \mathrm{C}, 60 \mathrm{~s}$ at $52^{\circ} \mathrm{C}$ and $120 \mathrm{~s}$ at $72^{\circ} \mathrm{C}$ were performed on a Biometra thermocycler. After 30 cycles the reaction temperature was maintained at $72^{\circ} \mathrm{C}$ for $10 \mathrm{~min}$ and then lowered to $4{ }^{\circ} \mathrm{C}$ for further storage.

A volume of $0.2-2 \mu 1$ of $100 \mu 1$ double-stranded PCR product was used to carry out cycle sequencing reactions to produce single strand PCR products, terminated by the four dideoxy nucleotides according to the protocol of Amersham Life Science (Braunschweig) 'Thermo sequenase fluorescent labelled primer cycle sequencing kit with 7-deaza-dGTP'. The following sequencing primers which were labelled with 'DyeAmidite 667' in a 'Gene assembler plus' (Pharmacia, Freiburg), were employed to obtain overlapping sequences: Mt-CCy 5'-*CTA/CCC ATG AGG A/CCA AAT A/CTC-3', Mt-LECy 5'-*TCA AAC CCG AAT GAT AC/TTT CCT ATT-3'; Mt-ECy 5'-* AAT AGG AAA/GTA TCA TTC TGG TTT GA-3', and S-Mt-BCy $5^{\prime}-{ }^{*}$ TCA AAA TGA TAT TTG TCC TC- $3^{\prime}$. PCR conditions: initially $3 \mathrm{~min}$ at $94^{\circ} \mathrm{C}$, then 30 cycles with $30 \mathrm{~s}$ at $94^{\circ} \mathrm{C}$ and $40 \mathrm{~s}$ at $60^{\circ} \mathrm{C}$; the vials were maintained at $4{ }^{\circ} \mathrm{C}$ after synthesis.

Products of the sequencing reactions were analysed with an automated DNA sequencer ('ALF-Express', Pharmacia, Freiburg). Gels: 11\% Hydrolink/urea (a total volume of $320 \mathrm{ml}$ contained $116 \mathrm{~g}$ urea, $35.2 \mathrm{ml}$ long-range hydrolink (Seachem), and $48 \mathrm{ml} \mathrm{10 \times} \mathrm{TBE)}$ solutions were filtered $(0.45 \mu \mathrm{m})$ and $40 \mathrm{ml}$ (to which $200 \mu \mathrm{l}$ APS and $20 \mu \mathrm{l}$ Temed were added) were used to produce $0.3 \mathrm{~mm}$ electrophoresis gels. Electrophoresis conditions: temperature $55^{\circ} \mathrm{C} ; 25 \mathrm{~W}, 60 \mathrm{~mA}, 800 \mathrm{~V}$; 700 min.

A second data set was analysed with a capillary sequencer. For PCR and DNA sequencing, the mitochondrial cytochrome $b$ gene was amplified from total DNA under the following conditions. Twenty-five microlitre reaction buffer contained: $1.5 \mathrm{mM} \mathrm{MgCl}_{2}, 10 \mathrm{mM}$ Tris-HCl, $100 \mu \mathrm{M}$ dNTPs, 0.8 units Taq polymerase (Pharmacia Biotech, Freiburg), $200 \mathrm{ng}$ DNA and 5 pmol PCR primer (mtFS-H 5'-TAG TTG GCC AAT GAT GAT GAT GGGTGT TCT ACT GGT T-3'; LA-FiS 5'-GTG ACT TGA AAR ACC ACC GTT G-3').

The PCR protocol initially involved $94^{\circ} \mathrm{C}$ for $4 \mathrm{~min} ; 31$ cycles with $94^{\circ} \mathrm{C}$ for $45 \mathrm{~s}, 52^{\circ} \mathrm{C}$ for $60 \mathrm{~s}$, $72^{\circ} \mathrm{C}$ for $120 \mathrm{~s}$; finally $72^{\circ} \mathrm{C}$ for $5 \mathrm{~min}$; PCR products were stored at $4{ }^{\circ} \mathrm{C}$. PCR products were precipitated in $4 \mathrm{M} \mathrm{NH}_{4} \mathrm{Ac}$ and $6 \mathrm{vol}$ ethanol. After centrifugation for $15 \mathrm{~min}$ at $13000 \mathrm{rpm}$, DNA pellets were washed in $70 \%$ ethanol and taken up in $10 \mu \mathrm{l}$ distilled water.

A cycle sequencing reaction (final volume $10 \mu \mathrm{l}$ ) was carried out in a next step. Reaction buffer consisted of: $2 \mu l$ reaction mix with BigDye terminators (according to the BigDye Terminator Protocol; ABI Applied Biosystems), 19 pmol primer (LA-FiS, mtD 5'-AAA TCC CAT TCC ACC CCT ACT ACT CCA CAA AAG A-3'). The cycle sequencing was carried out in 25 cycles at $96^{\circ} \mathrm{C}$ for $10 \mathrm{~s}, 52^{\circ} \mathrm{C}$ for $5 \mathrm{~s}$ and $60^{\circ} \mathrm{C}$ for $4 \mathrm{~min}$.

Sequencing products were purified by precipitation: 1 vol reaction mix, 0.1 vol $3 \mathrm{M}$ NaAcetate ( $\mathrm{pH} 4.6$ ), $2.5 \mathrm{vol}$ ethanol. After centrifugation for $15 \mathrm{~min}$ at $13000 \mathrm{rpm}$, DNA pellets were washed in $70 \%$ ethanol and taken up in $20 \mu \mathrm{l}$ distilled water. The purified was diluted 1:5 in water and applied to a 16 column automatic capillary sequencer (ABI 3100) using $50 \mathrm{~cm}$ capillaries and POP6 as a polymer.

The sequences were aligned to the cytochrome $b$ sequence of Marcusenius macrolepidotus which was also used as an outgroup. Sequence data, whose informative characters are shown in Table 6, have been deposited in the Sequence Library of EMBL (accession numbers for P. marianne: AY234063AY234096 excepting AY234082, AY234099; for P. castelnaui: AY234097, AY234098, AY234100AY234103, AY236979). Phylogenetic trees were reconstructed by the character state method maximum parsimony (MP; program PAUP 4.0b8; Swofford 2001), the distance matrix method neighbour joining (NJ) and maximum likelihood analysis (ML). In NJ analyses, evolutionary distances were calculated based on the Kimura 2 parameter algorithm, which corrects for any bias in transition/transversions and uneven codon usage. Bootstrap analyses were performed to obtain confidence estimates for each furcation. In MP a heuristic search (addition sequence nearest; swapping algorithm: TBR; MULPARS OPTION) was carried out. Results are illustrated as clado- or phylograms (in phylograms, branch lengths are proportional to the number of inferred changes or evolutionary distances).

\section{Comparative material}

P. castelnaui (Boulenger, 1911), syntypes BMNH no. 1910.5.31: 11-12 (2), two specimens of 6.0 and $6.4 \mathrm{~mm}$ SL, type locality: 'Lake Ngami' (Boulenger 1911: p. 400) [however, Boulenger states that the name of this locality is used for convenience only, the real origin being the 'Okavango River and vast extent of marshes (of which Lake Ngami is a part)'; by contrast, 
Bell-Cross \& Minshull (1988: p. 110) clearly specify that R. B. Woosman collected the types from the Okavango River (Figure 2), however, a specific place is not given],

- seven specimens from Nkasa Island $\left(18^{\circ} 27^{\prime} \mathrm{S}\right.$, $23^{\circ} 42^{\prime} \mathrm{E}$ ) in Mamili National Park (transition of the Kwando River to Linyanti Swamps), 9-10 September 1993, water conductivity and temperature, $108 \mu \mathrm{S} \mathrm{cm}^{-1}, 18-19^{\circ} \mathrm{C}$, size range $34.5-60 \mathrm{~mm}$ SL;

- 24 specimens from the Kwando River, Nakatwa, $18^{\circ} 06^{\prime} \mathrm{S}, 23^{\circ} 23^{\prime} \mathrm{E}$, in Mudumu National Park, 9-15 March 1994, water conductivity and temperature, $130 \mu \mathrm{S} \mathrm{cm}^{-1}, 24.9^{\circ} \mathrm{C}$, size range $21-55 \mathrm{~mm} \mathrm{SL}$;

- 12 specimens from Linyanti Swamp: Sampis, $18^{\circ} 04^{\prime} 59.6^{\prime \prime} \mathrm{S}, 24^{\circ} 02^{\prime} 7^{\prime \prime} \mathrm{E}, 8$ April 1996 , water conductivity and temperature, $100 \mu \mathrm{S} \mathrm{cm}^{-1}$ and 25-26 $\mathrm{C}$, size range $47.2-59 \mathrm{~mm} \mathrm{SL}$;

- five specimens from the Kwando River at Kongola bridge, $17^{\circ} 47^{\prime} 33^{\prime \prime} \mathrm{S}, 2^{\circ} 20^{\prime} 33^{\prime \prime} \mathrm{E}, 10$ April 1996, water conductivity and temperature, $100 \mu \mathrm{S} \mathrm{cm}^{-1}$ and $25-26^{\circ} \mathrm{C}$, size range $49.5-60.7 \mathrm{~mm} \mathrm{SL}$;

- 29 specimens from Linyanti Swamp: Sampis, $18^{\circ} 04^{\prime} 59.6^{\prime \prime} \mathrm{S} 24^{\circ} 02^{\prime} 7^{\prime \prime} \mathrm{E}, 8-10$ September 1997 , water conductivity and temperature, $156.8 \mu \mathrm{S} \mathrm{cm}^{-1}$ and $21.3^{\circ} \mathrm{C}$, size range $41.8-67.1 \mathrm{~mm}$ SL;

- 16 specimens from Kwando River at Kongola bridge, $17^{\circ} 47^{\prime} 33^{\prime \prime} \mathrm{S}, 23^{\circ} 20^{\prime} 33^{\prime \prime} \mathrm{E}, 25$ August 1999, water conductivity and temperature, $236 \mu \mathrm{S} \mathrm{cm}^{-1}$ and $19^{\circ} \mathrm{C}$, size range 31.9-60.2 $\mathrm{mm}$ SL;

- 35 specimens from the Okavango Delta, close to Makwena River Camp near locality Etsha $10,1^{\circ} 03^{\prime} 16.2^{\prime \prime} \mathrm{S}, 22^{\circ} 22^{\prime} 51.3^{\prime \prime} \mathrm{E}, 20-21$ January 2001 , water conductivity and temperature, $29.9^{\circ} \mathrm{C}$, $37 \mu \mathrm{S} \mathrm{cm}^{-1}$, size range $35.1-56.8 \mathrm{~mm} \mathrm{SL}$;

- two specimens from Kwando River at Kongola bridge, $17^{\circ} 47^{\prime} 33^{\prime \prime} \mathrm{S}, 23^{\circ} 20^{\prime} 33^{\prime \prime} \mathrm{E}, 24$ January 2001 , water conductivity and temperature, $160 \mu \mathrm{S} \mathrm{cm}^{-1}$ and $26.6^{\circ} \mathrm{C}$, size range $50.9-61 \mathrm{~mm}$ SL.

EOD only: Three specimens from the west side of the panhandle of the Okavango where it starts to fan out, Guma Lagoon, sandbar at N inlet, $18^{\circ} 57^{\prime} 30.6^{\prime \prime} \mathrm{S}$, $22^{\circ} 23^{\prime} 12.0^{\prime \prime} \mathrm{E}$, site no. OK1-10 of the AquaRAP expedition, 23 June 2000, water conductivity and temperature, $34.5-35.4 \mu \mathrm{S} \mathrm{cm}^{-1}, 19.2-20.2^{\circ} \mathrm{C}$, size $35.7,50.8$ and $5.86 \mathrm{~mm}$ SL.

Anatomy only: Thirty SAIAB (RUSI) specimens, all from the Okavango Delta: SAIAB (RUSI) 028911, four specimens from Xakanaxa or Xakanixa Lagoon, Moremi Game Reserve, Okavango Delta (location R2, Figure 2), 6 October 1985, size range 46.9$53.8 \mathrm{~mm}$ SL, G. Merron collector; SAIAB 023021, five specimens from same location, 11 October 1984 , size range $36.8-57.6 \mathrm{~mm}$ SL, M. N. Bruton collector; SAIAB 023075, six specimens from same location, 12 December 1984, size range 43.5-54.1 mm SL, P. Skelton collector; SAIAB 021119, ten specimens from Chanoga Lagoon, Botletli River, $20^{\circ} 10 \mathrm{~S}^{\prime}$, $23^{\circ} 40^{\prime}$ E (location R3, Figure 2), 19 March 1984, size range $36.8-64.6 \mathrm{~mm}$ SL, G. Merron collector; SAIAB 062840, one specimen from Botswana Channel upstream from Drotsky’s Lodge, $18^{\circ} 24^{\prime} 31^{\prime \prime} \mathrm{S}$, $21^{\circ} 53^{\prime} 10^{\prime \prime} \mathrm{E}$ (location R5, Figure 2), 7 June 2000, size $56.5 \mathrm{~mm}$ SL, R. Bills collector; SAIAB 062842, two specimens from Botswana Shakawe Fishing Lodge, $18^{\circ} 26^{\prime} 05^{\prime \prime} \mathrm{S}, 21^{\circ} 54^{\prime} 21^{\prime \prime} \mathrm{E}$ (location R5, Figure 2), 9 June 2000, size range 50.3-58 mm SL, R. Bills collector; SAIAB 062843, one specimen from Maunachira Channel, $19^{\circ} 08^{\prime} 58^{\prime \prime} \mathrm{S}, 23^{\circ} 16^{\prime} 44^{\prime \prime} \mathrm{E}$ (location R1, Figure 2), 14 June 2000, size $46.2 \mathrm{~mm}$ SL, R. Bills collector; SAIAB 062845, one specimen from Sepopa, Du Plessis' Camp, $18^{\circ} 44^{\prime} 39^{\prime \prime} \mathrm{S}, 22^{\circ} 11^{\prime} 47^{\prime \prime} \mathrm{E}$ (location R4, Figure 2), size $40.4 \mathrm{~mm}$ SL, R. Bills collector.

Allozyme study: Five specimens from Kongola $\left(17^{\circ} 47^{\prime} 33^{\prime \prime} \mathrm{S}, 23^{\circ} 20^{\prime} 33^{\prime \prime} \mathrm{E}\right), 10$ April 1996, [code nos Kw150, Kw154, Kw156, Kw157 and Kw158; 24 individuals from Lisikili $\left(17^{\circ} 29^{\prime} \mathrm{S}, 24^{\circ} 26^{\prime} \mathrm{E}\right), 7$ April 1996 , code nos Ka76, Ka79, Ka82, Ka84, Ka85, Ka87, Ka129, Ka132, Ka135, Ka137, Ka78, Ka80, Ka81, Ka86, Ka88, Ka89, Ka90, Ka127, Ka128, Ka130, Ka133, Ka134, Ka136, Ka138; and eight individuals from Sampis (18 $\left.04^{\prime} 59^{\prime \prime} \mathrm{S}, 24^{\circ} 02^{\prime} 07^{\prime \prime} \mathrm{E}\right), 8$ April 1996, code nos Lin01, Lin02, Lin04, Lin05, Lin06, Lin08, Lin09, Lin11]; and an additional 30 EOD Type 1 individuals (from Makwena Lodge, Okavango; same locality description as above) were also included.

DNA study: Five specimens from Lisikili, Zambezi River, 7 April 1996, size range 54.8-65.9 mm SL; eight specimens from Sampis at Linyanti Swamp, 8 April 1996, size range 47.2-59 mm SL; additional material for DNA study only: five specimens from Buffalo Camp (Nakatwa, Kwando River), $18^{\circ} 09^{\prime} 40^{\prime \prime} \mathrm{S}, 23^{\circ} 23^{\prime} 09^{\prime \prime} \mathrm{E}, 24$ February 1997.

Pollimyrus marianne, sp. nov.

Figures 1,3,4,6,7

Tables $1,2,3,4,5,6,7$ 
Material examined

Seven specimens from Zambezi River, Katima Mulilo, rocks in middle of river (opposite boat landing), $17^{\circ} 29^{\prime} \mathrm{S}, 24^{\circ} 18^{\prime} \mathrm{E}, 11$ Sept. 1993 , water conductivity and temperature, $81 \mu \mathrm{S} \mathrm{cm}^{-1}, 21.8^{\circ} \mathrm{C}$, size range $42.5-66.5 \mathrm{~mm} \mathrm{SL}$,

- seven specimens from Zambezi River, Lisikili backwater, $17^{\circ} 29^{\prime} \mathrm{S}, 24^{\circ} 26^{\prime} \mathrm{E}, 5-7$ March 1994 , water conductivity and temperature, $56.1 \mu \mathrm{S} \mathrm{cm}^{-1}, 26.8^{\circ} \mathrm{C}$, size range 40-56 $\mathrm{mm} \mathrm{SL}$,

- 91 specimens from Zambezi River, Lisikili backwater, $17^{\circ} 29^{\prime} \mathrm{S}, 24^{\circ} 26^{\prime} \mathrm{E}, 7$ April 1996, water conductivity and temperature, $66 \mu \mathrm{S} \mathrm{cm}^{-1}$ and $25.8^{\circ} \mathrm{C}$, size range $45.3-72.8 \mathrm{~mm}$ SL.

\section{Holotype}

SAIAB 66943, $68 \mathrm{~mm}$ SL (6.1 $\mathrm{mm}$ in $70 \%$ alcohol), female, 7 April 1996, collection data: as given in preceding paragraph. Coll. B. Kramer and F.H. van der Bank. Field code: Ka97.

\section{Paratypes}

SAIAB 66944, 10 specimens, size range $62.1-70.6 \mathrm{~mm}$ SL, collection data: same as holotype. Field codes: Ka93, Ka95, Ka100, Ka105, Ka106, Ka108, Ka159, Ka163, Ka169, Ka171.

\section{Diagnosis}

Usually 16 (13-18) SPc, 17 (14-19) nD, 23 (21-26) nA; PDL (1.45-1.59-1.79), PAL (1.61-1.75-2.04), LD (4.98-5.73-6.73), LA (3.87-4.35-6.09), pD (1.872.42-3.78), CPL (3.87-4.39-5.07), CPD (11.8-14.0516.8), LS $_{\mathrm{c}}(11.3-12.63-14.13)$, HL (3.21-4.32-4.73), BD (3.46-3.84-4.97) times included in SL; EOD with only three phases (P1, N and P2), P1 stronger than $\mathrm{P} 2$, sometimes miniature potentials riding on P1 (definitions, Figure 4); EOD of longer duration than in P. castelnaui from the Okavango $\left(1-1.3 \mathrm{~ms}\right.$ at $25^{\circ} \mathrm{C}$, $\mathrm{N}=12$ rather than $0.83-1 \mathrm{~ms}, \mathrm{~N}=12$ ).

\section{Description}

The head is broadly rounded with a small terminally positioned mouth; head and body dorsolaterally compressed. Dorsal fin origin (a) situated about two thirds of standard length from snout, (b) obliquely oriented with anteriorly higher and posteriorly lower, (c) in some specimens, distal margin crescentic with first few anterior rays longer than those posteriorly and (d) median number of rays 17 (14-19). Anal fin (a) opposite dorsal fin but origin more anteriorly and also obliquely oriented, (b) anteriorly lower and posteriorly higher, (c) in some male specimens, anterior 10 or so rays longer than those posteriorly, (d) margin broadly rounded, (e) rays posterior to first 10 with distal margin straight and (f) median number of rays 23 (21-26). Scales (a) cycloid with reticulate striae, except in centre, (b) extending anteriorly to operculum, pectoral fins and pelvic fins. SPc, median 16 (13-18). Caudal peduncle slender and subcylindrical over the entire length, usually less than a quarter in SL. Tail fin with broadly rounded lobes. EOD triphasic with strong head-positive (P1), very strong head-negative $(\mathrm{N})$, and weak second headpositive phase (P2); long duration, usually $1-1.3 \mathrm{~ms}$ at $25^{\circ} \mathrm{C}, \mathrm{N}=12$; Figure 4). Unusual brown mottled colour for a mormyrid; belly and underside of head, light beige densely covered with brown spots.

\section{Colour in preservation}

Brown mottled colour.

\section{Ecology}

P. marianne was sampled from fast-flowing sections of the Upper Zambezi River at Katima Mulilo with rapids and rocky bottom where there was little cover, except for crevices and rock holes, and also from dense reed beds on sandy bottom and weak current, from kneedepth to chest-depth using hoop nets (Zambezi secondor third order side-channel at Lisikili). At the same location, also from within floating reed mats about $1 \mathrm{~m}$ thick.

\section{Distribution}

At present only known from the Upper Zambezi River: Eastern Caprivi: Katima Mulilo and Lisikili (see map of Figure 2). A few specimens of Type 3 EOD waveform have also been observed in the Kwando/Linyanti system that has repeatedly been flooded by the Zambezi (see Discussion).

\section{Relationships}

P. marianne is considered closest to P. castelnaui based on the confusion of the identity of the two species. The clearest distinction is by EOD waveform (three phases in $P$. marianne, five in $P$. castelnaui), and by the number of SPc (16 versus 12, respectively, with almost no overlap between the populations). As suggested in the present study, a third species exhibiting 
(a)

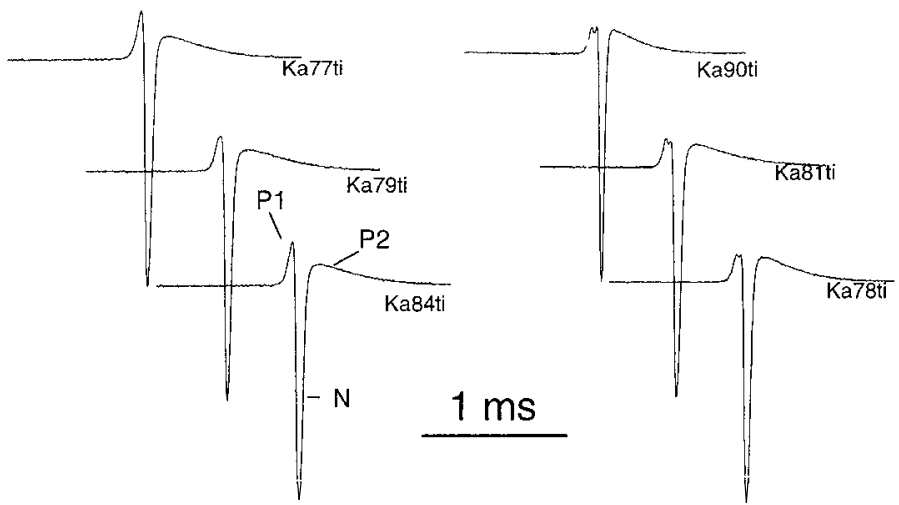

(b)



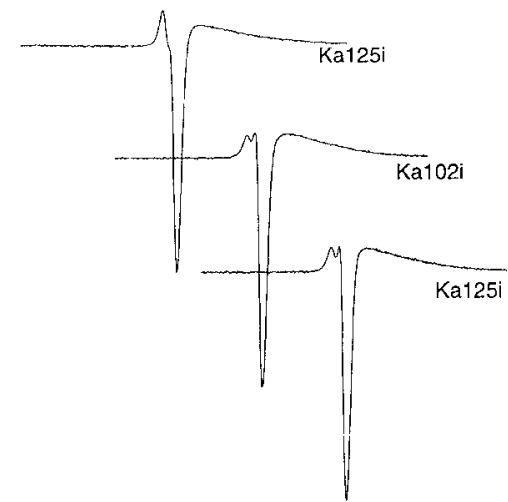

(c)



Figure 4. Oscillograms of EODs in samples of the Pollimyrus complex from Caprivi (a,b) and Okavango (c) (Volts over time). Each trace is one individual (with identity code). Ordinate, linear Volts normalised to the same peak amplitude of the head-negative main phase, $\mathrm{N}$; head-positivity is up. Abscissa, time in ms as indicated by time bar (same scale everywhere). (a) Left, three examples for the simplest EOD waveform in P. marianne as sampled from Lisikili (Zambezi River). (a) Middle, right, six examples for a slight increase in complexity of the first head-positive phase, P1, also in P. marianne from Lisikili. P2, last head-positive phase. (b) Six examples from the Kwando River/Linyanti Swamp showing great complexity and high variability in EOD waveform (two specimens each coded by Kw... from Kongola; N. .., Nakatwa; Li. .., Linyanti Swamp). (c) Three examples of P. castelnaui from Okavango. Prepotentials, in fish from Kwando System and Okavango, only: p, preceding head-positive potential; n, preceding head-negative potential. EODs normalised to $25^{\circ} \mathrm{C}$ if not recorded at that temperature.

a clinal variation may have arisen from hybridisation between the two species in the geographically intermediate Kwando/Linyanti system. The Kwando/Linyanti phenotype is best characterised by its EOD waveform which is closer to that of $P$. castelnaui by its five phases but shows a high P1/P2 amplitude ratio more similar to that of $P$. marianne.

\section{Etymology}

P. marianne is named in honour of Marianne Elfriede Kramer (born 3 October 1914 in Bremen, deceased 13 November 2000 in Frankfurt/Main), mother of B.K.

\section{Results}

The dwarf stonebasher, P. castelnaui (Boulenger, 1911), probably is the smallest living mormyrid (maximum SL, little more than $7 \mathrm{~cm}$ ). Apart from its small adult size there is no very distinctive characteristic that would allow quick discrimination from immatures of some of the other sympatric mormyrid species. However, fish routinely considered P. castelnaui are unique by the broad range of habitats and types of daytime shelter they are capable of using. Fish originally considered P. castelnaui were sampled from habitats as diverse as (i) fast-flowing sections of the Upper 
Zambezi at Katima Mulilo with rapids and rocky bottom where there is little cover, except for crevices and rock holes; (ii) in dense reed beds on sandy bottom and weak current (Zambezi second-or third order side-channel at Lisikili); (iii) dense, rooted vegetation in soft-bottomed, stagnant channels of the Linyanti and Kwando close to (or under) the banks; (iv) same as (iii) except for specimens hiding under the floating leaves of small patches $\left(\sim 0.3 \mathrm{~m}^{2}\right)$ of water-lilies and other surface floating plants, away from the banks. The last habitat is most unusual for a mormyrid which as a rule seek day-time cover in dark places, that is, usually the bottom. Perhaps these fish were driven to the surface with its unfavourably strong light intensity by bottomoriented predators. In the Okavango P. castelnaui was mainly observed in dense, rooted or unrooted (floating) vegetation bordering river banks with soft muddy bottom.

P. castelnaui, therefore, seemed to be a rather eurytopic species, capable of adapting to a broader range of habitats than most other mormyrids, at least in this area. Alternatively, two or more locally well-adapted, genetically differentiated species or subspecies of Pollimyrus could occur only in certain types of habitat. Our discovery of different EOD phenotypes in different parts of the Upper Zambezi System within Caprivi initiated the present study.

We here present evidence for parapatric speciation in fish routinely considered $P$. castelnaui in Caprivi, contrasting them with $P$. castelnaui from the Okavango. We show that these electrical phenotypes correlate with morphological phenotypes, taking the type material studied by Boulenger (1911) as a reference. We then examine the evidence for genetic differentiation among our local EOD phenotypes.

\section{Electric organ discharges}

EODs from Okavango samples of $P$. castelnaui are shown here for the first time. There are five phases: (very) weak positive (p), weak negative (n), relatively strong positive-going $(\mathrm{P} 1)$, negative main spike $(\mathrm{N})$, strong positive (P2; Figure 4C). EOD duration is brief $\left(0.83-1 \mathrm{~ms}, \mathrm{~N}=12,25^{\circ} \mathrm{C}\right)$. Interindividual variability in phase amplitudes is low ( $N=33$, Figure 5), and the characteristic EOD waveform pattern is termed a Type 1 EOD in the present paper.

Zambezi samples ( $N=105$, Table 1$)$ display a categorically different EOD waveform of longer duration $\left(1-1.3 \mathrm{~ms}\right.$ at $\left.25^{\circ} \mathrm{C}, \mathrm{N}=12,25^{\circ} \mathrm{C}\right)$. There are only three phases: P1, N and P2 (Figure 4A). It is termed a Type 3 waveform. In some specimens' EODs, P1 is indented by what looks like delayed 'incipient' or rudimentary $\mathrm{p}$ and $\mathrm{n}$ phases of miniature amplitude, starting only when P1 is close to its peak amplitude (Figure 4A, middle and right; Subtype 3 waveform). Sometimes the miniature potentials appear so much delayed they ride on the steeply descending slope of the $\mathrm{P} 1$ phase leading into the $\mathrm{N}$ phase (for example, fish Ka125i of Figure 4A). Whereas at Lisikili (Figure 2, location b) the simple Type 3 waveform predominated (63 versus 35), further upstream at Katima Mulilo (location a) all of our seven individuals showed the Subtype 3 EOD waveform (with indented P1 phase). Based on the geographic separation of categorically different waveforms, it is concluded that our Zambezi

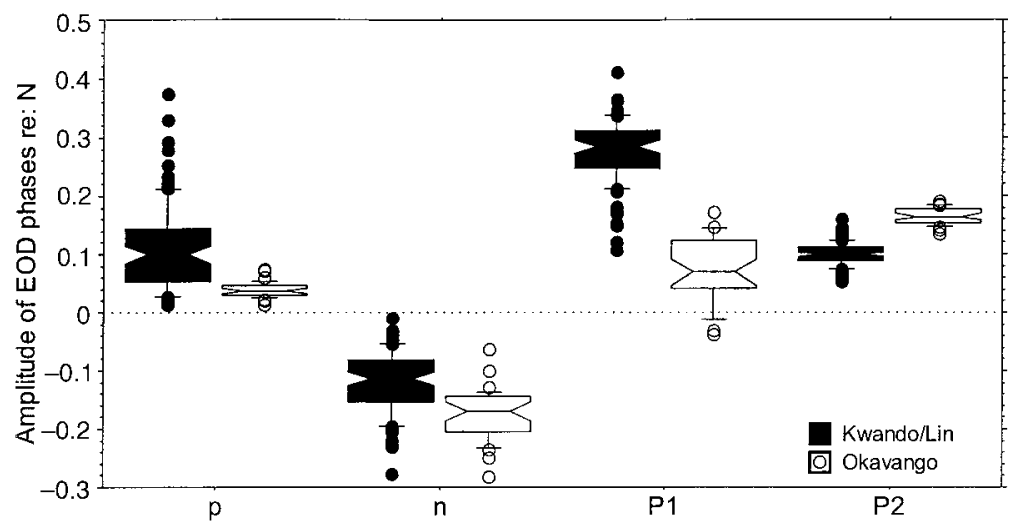

Figure 5. Comparison of EODs from P. castelnaui specimens from Okavango $(\mathrm{N}=33$, white) and from the Kwando/Linyanti system ( $\mathrm{N}=86$, black). Ordinate: amplitude peaks of the different phases of an EOD ( $\mathrm{p}, \mathrm{n}, \mathrm{P} 1$, P2; shown in Figure 4), as normalised to $\mathrm{N}$ phase $=-1$. The waist of each box is the median; also given are (from median out): the $95 \%$ confidence limits; the 25 th and 75 th percentiles as lower and upper box boundaries, respectively; the 10th and 90th percentiles as 'whiskers'; outliers as dots. 
Table 1. Geographical distribution of EODs of different waveform types as recorded from samples of the Pollimyrus complex (EOD types, see Figure 4). The body of the table gives numbers of individuals. For sampling locations, see map in Figure 2.

\begin{tabular}{llccc}
\hline Origin & \multicolumn{4}{c}{ EOD waveform } \\
\cline { 2 - 5 } & Type & Type & Type & Subtype \\
& 1 & 2 & 3 & 3 \\
\cline { 2 - 5 } (a) Katima (UZ) & 0 & 0 & 0 & 7 \\
(b) Lisikili (UZ) & 0 & 0 & 63 & 35 \\
(c) Sampis (Kw) & 0 & 33 & 6 & 0 \\
(d) Nkasa Island (Kw) & 0 & 7 & 0 & 0 \\
(e) Nakatwa (Kw) & 0 & 23 & 0 & 0 \\
(f) Kongola (Kw) & 0 & 23 & 1 & 0 \\
(g,h) Okavango & $3+33$ & 0 & 0 & 0 \\
\hline
\end{tabular}

UZ - Upper Zambezi.

$\mathrm{Kw}$ - Kwando River System (including Linyanti Swamp). (a)-(h) see map in Figure 2.

samples were drawn from a taxon that is distinct from P. castelnaui.

Most samples from the geographically intermediate Kwando/Linyanti system show a Type 2 EOD waveform (Figure 4B). Like Type 1, a Type 2 waveform exhibits five phases; however, $\mathrm{p}$ and $\mathrm{n}$ phases are of roughly equal amplitudes that vary greatly in relation to $\mathrm{P} 1$ and $\mathrm{P} 2$, from small to much stronger than these. Also in contrast to Type $1, \mathrm{P} 1$ is stronger than $\mathrm{P} 2$ in Type 2 EODs. Compared to Type 1, a Type 2 EOD exhibits great variability in waveform (Figure 5) and EOD duration: $0.8-1.225 \mathrm{~ms}$ in fish from Linyanti, $1.05-1.41 \mathrm{~ms}$ in fish from the Kwando $(\mathrm{N}=12$ and $25^{\circ} \mathrm{C}$ in both cases).

EODs of waveform Type 2 were exclusively observed in fish originating from the Kwando/Linyanti River system. The location nearest to the Zambezi (Linyanti Swamp) also held a few individuals of a Type 3 waveform (6 versus 33). The presence of a few Type 3 EODs in the Kwando/Linyanti system seems related to the recent flooding history by the Zambezi River (see Materials and methods), and we sampled only a single individual of a Type 3 waveform versus 51 individuals of a Type 2 waveform from our locations further upstream on the Kwando System (Figure 2, locations $d$, e and $f$ combined). Apart from these few exceptions regarding Type 3, EOD waveform types were firmly separated geographically: each one of our 105 fish sampled from the Zambezi showed a waveform of Type 3 or Subtype 3 (Table 1). Likewise, each one of our $\mathrm{N}=36$ samples of live $P$. castelnaui sampled from the Okavango displayed a Type 1 EOD waveform (Table 1).

Type 2 EODs from Kwando/Linyanti specimens are categorically different from Zambezi specimens' Type 3 EODs, and thus must represent a different taxon. The population of Type 2 EODs (Kwando/Linyanti) is also distinct from the population of Type 1 EODs (Okavango), even though the differences between them are of a more gradual nature: Peak amplitudes for the different EOD phases (p, n, P1 and P2) for Okavango samples and Kwando/Linyanti samples, as referenced to $\mathrm{N}$ phase amplitude equal to -1 , were compared (Figure 5); excluding, of course, the few Type 3 EODs observed in the Kwando/Linyanti system. The null hypothesis that the peak amplitude differences between Kwando/Linyanti EODs $(\mathrm{N}=86)$ and Okavango EODs $(\mathrm{N}=33)$ are due to random sampling error is clearly rejected by a multivariate analysis of variance (MANOVA; $\mathrm{P}<0.0001$ for Wilk's Lambda, Roy's Greatest Root, Hotelling Lawley Trace and Pillai Trace tests). A MANOVA rather than a series of independent t-tests for the pairwise comparison of means (or their non-parametric equivalent) was chosen to avoid overestimating the significance of differences by possible correlations in peak amplitudes among the various EOD phases measured in the same EODs. ANOVAs subsequent to MANOVA show that the peak amplitudes for all four EOD phases (p, n, P1 and $\mathrm{P} 2$ ), when compared pairwise, significantly depend on origin ( $\mathrm{P}<0.0001$ for each comparison).

It is concluded that, based on EOD waveform, Kwando/Linyanti samples represent a taxon distinct from $P$. castelnaui, as well as distinct from the Zambezi phenotype. The Type 2 EOD of Kwando/Linyanti specimens combines features of the $P$. castelnaui EOD (five phases rather than three) with that of the Zambezi Type 3 of EOD (P1 phase amplitude $\geq \mathrm{P} 2$ ), in a unique way that is found in neither of the two major river systems on either side, Okavango and Zambezi.

\section{Morphology}

From inspection of means and medians, morphological differences between our samples from different origins are apparent that cannot be ignored off-hand (Table 2, Figure 6). For example, there are 12 scales around the caudal peduncle in both syntype specimens, confirmed by a median of $12 \pm 0.25$ (SIQ) in our own, bigger sample from the Okavango. Going east, the number of scales increases steadily with distance: a median of $14 \pm 1$ (SIQ) scales in specimens from the Kwando, 


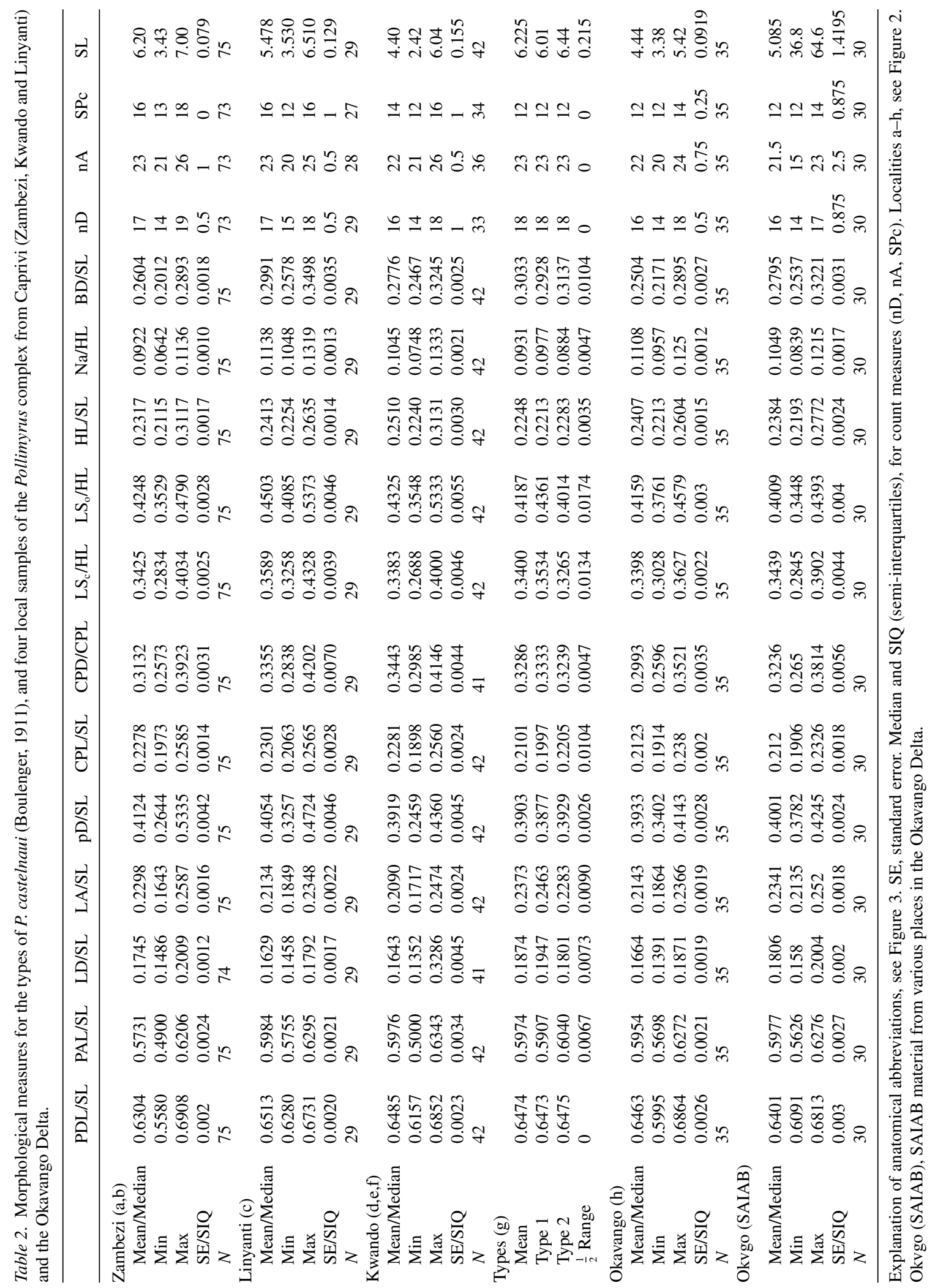





Figure 6. Comparison of morphological measures for the types of P. castelnaui (I) with (1) three local forms of the Pollimyrus complex from Caprivi (Zambezi, Linyanti and Kwando, hatching as indicated by code), (2) our present sample of $P$. castelnaui from the Okavango and (3) SAIAB museum material for P. castelnaui from various places of the Delta (SAIAB-Okv, combined to form a single group). Shown are means $+1 \mathrm{SE}$ (if not too small to be drawn), or medians +1 SIQ for count measures (SIQ, semiinterquartile). In types $(\mathrm{N}=2)$, SE or SIQ replaced by $\frac{1}{2}$ range. For abbreviations of morphological characters, see Materials \& methods. For sample sizes and definition of relative length measures, see Table 2.

$16 \pm 1$ (SIQ) scales in fish from the Linyanti, and $16 \pm 0$ (SIQ) scales in fish from the Zambezi (for the latter two, means are 14.85 and 15.72 , respectively). Our first question, therefore, was whether the morphological variation encountered in this and other characters represents random sampling error. Because morphological characters measured on the same set of individuals are correlated amongst each other, MANOVA were employed that take into account shared information between dependent variables. A MANOVA (performed on all morphological characters that were included in the study simultaneously) clearly rejects the null hypothesis of no morphological difference between our samples from the Okavango and different origins within Caprivi ( $\mathrm{P}<0.0001$, Table 3).

Subsequent univariate ANOVAs identify the source of this variability. Seen from the side, the Zambezi samples show a relatively shorter anterior (rostral) fish section than samples from the other locations, as indicated by their low PDL and PAL values $(\mathrm{P}<0.01$, Table 3). The Zambezi samples also differ significantly from all other samples studied in LD, LA, CPD, $\mathrm{HL}, \mathrm{Na}$ and $\mathrm{BD}$; from Okavango samples, they differ in addition in $\mathrm{pD}, \mathrm{CPL}, \mathrm{nD}, \mathrm{nA}$ and SPc. That is, Zambezi samples differ from Okavango samples in every morphological character studied except $\mathrm{LS}_{\mathrm{c}}$, or in 13 characters. On morphological grounds, it is concluded that the Zambezi samples are drawn from a taxon that is distinct from P. castelnaui.

In contrast, no clear morphological distinction is found between Kwando and Linyanti samples that offer significant differences in three characters only, $\mathrm{HL}, \mathrm{Na}$ and $\mathrm{BD}$, all of which are considered of limited systematic relevance in the present case. BD is known to strongly depend on food availability, which probably was higher in the more swampy Linyanti region than in the Kwando River. In samples of different average size such as here (Kwando samples being smaller, again, lower food availability), there is a risk of HL and $\mathrm{Na}$ being affected by allometric growth.

Kwando and Linyanti samples both differ from Okavango samples in SPc, CPL, CPD, $\mathrm{LS}_{\mathrm{c}}$ and $\mathrm{nD}$ (nD for Linyanti samples only). Kwando and Linyanti samples differ from Zambezi samples in PDL, PAL, $\mathrm{LD}, \mathrm{LA}, \mathrm{CPD}, \mathrm{HL}, \mathrm{Na}$ and $\mathrm{BD}$; in addition $\mathrm{pD}$ and SPC for Kwando samples only, and in addition $\mathrm{LS}_{\mathrm{c}}$ for Linyanti samples only. On morphological grounds the Kwando/Linyanti population appears distinct from both populations present in the neighbouring major river systems, the Okavango and the Zambezi. The Kwando/Linyanti population appears, however, to be somewhat closer in morphology to the Okavango population than to that of the Zambezi, in contrast to the present status of the Kwando/Linyanti system as a tributary of the Zambezi River.

Thirty SAIAB specimens from the Okavango Delta were compared with the present sample from Makwena Lodge on the Okavango River. In the first analysis, the SAIAB specimens were treated as a single group, although 16 specimens were sampled from locations 


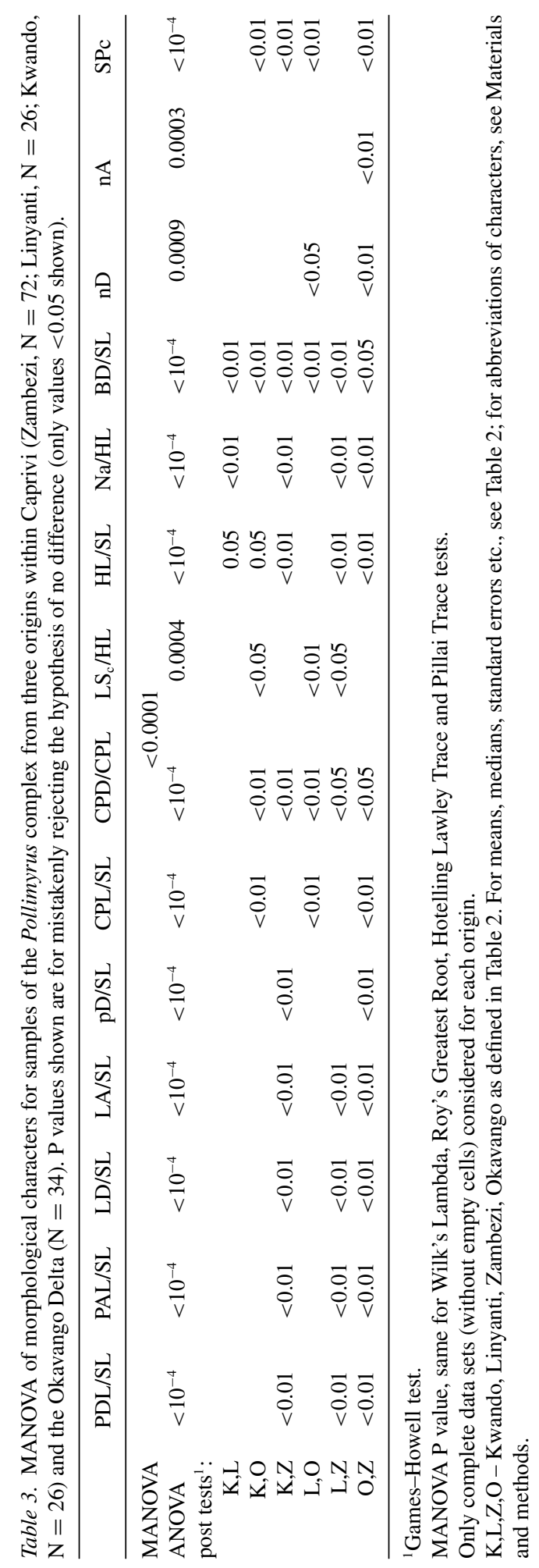


in the north-eastern part of the Delta (R1 and R2, Figure 2), ten specimens from a location in its South (R3), and four specimens from the North-West (R4 and R5). MANOVA revealed significant differences between the combined SAIAB group and our Makwena sample in $\mathrm{Na}, \mathrm{BD}, \mathrm{CPD}, \mathrm{LA}$ and LD. Whereas $\mathrm{Na}$ and $\mathrm{BD}$ are considered of limited significance (see above), the higher values for CPD, LA and LA in SAIAB specimens compared to our Makwena specimens would signal population differences within the Delta. This is confirmed by the second analysis: a comparison of samples from locations $\mathrm{R} 2(\mathrm{~N}=15)$ and $\mathrm{R} 3(\mathrm{~N}=10)$. MANOVA $(\mathrm{P}<0.01)$ followed by ANOVAs revealed significant differences between the two populations which are due to $\mathrm{nA}$ (median $21 \pm$ SIQ 2.75 in R2 samples vs. median $22 \pm$ SIQ 0.5 in R3 samples, $\mathrm{P}=0.0174$ ), and $\mathrm{Na}$. Surely the population differences within the Delta merit closer study.

\section{Genetics}

Some of the samples studied for EOD and morphology were also analysed for DNA $(\mathrm{N}=13)$ and allozyme $(\mathrm{N}=67)$ polymorphism. Four (30) Type 1 individuals from Okavango, eight (13) fish from Sampis/Linyanti Swamp displayed an EOD waveform of Type 2, and the five (24) fish from Lisikili/Zambezi a waveform of Type $3(\mathrm{~N}=1 ; 10)$ or Subtype $3(\mathrm{~N}=4 ; 14$; second numbers for allozymes). For additional DNA samples, refer to Tables 6 and 7, and Figures 7 and 8 .

\section{Allozyme study}

Of the 28 protein-coding loci that provided interpretable results (i.e. which showed sufficient activity and resolution for scoring), 12 (42.9\%) were polymorphic in one or more of the wave types studied (Table 4). Four alleles were observed at the MPl locus, three at the GPI-2 and IDH loci, whereas all of the other polymorphic protein coding loci had only two alleles. All waveform types had the EST-1*A,-2*A, $L D H-1 * B$,$2 * B, M D H-1 * B,-2 * A$ and $P E P-C 2 * C$ alleles in the highest frequency, whereas the Type 1 individuals had rare $E S T-1 * B,-2 * B, G P I-2 * B$ and $M D H-1 * A$ alleles (Table 4).

The genetic distances $D_{78}$ (Nei 1978) were calculated from the observed allele frequencies at all 28 protein-coding loci. The $\mathrm{D}_{78}$ values (specially adapted for small sample sizes), vary from 0.006 to 0.028 for these wave types respectively, and average 0.018
Table 4. Allele frequencies for four types of EOD waveform of the Pollimyrus complex.

\begin{tabular}{llllll}
\hline Locus: & Allele: & Type 1 & Type 2 & Type 3 & Subtype 3 \\
\hline EST-1 & $\mathrm{A}$ & 0.867 & & & \\
& $\mathrm{~B}$ & 0.133 & 1.000 & 1.000 & 1.000 \\
EST-2 & $\mathrm{A}$ & 0.867 & & & \\
& $\mathrm{~B}$ & 0.133 & 1.000 & 1.000 & 1.000 \\
GPI-1 & $\mathrm{A}$ & & 0.052 & & \\
& $\mathrm{~B}$ & 0.138 & 0.474 & 0.050 & \\
& $\mathrm{C}$ & 0.862 & 0.474 & 0.950 & 1.000 \\
GPI-2 & $\mathrm{A}$ & 0.786 & & & \\
& $\mathrm{~B}$ & 0.214 & 1.000 & 1.000 & 1.000 \\
IDH & $\mathrm{A}$ & 0.727 & 0.333 & & \\
& $\mathrm{~B}$ & 0.205 & 0.556 & & 0.833 \\
& $\mathrm{C}$ & 0.068 & 0.111 & 1.000 & 0.167 \\
LDH-1 & $\mathrm{A}$ & & 0.219 & 0.071 & 0.273 \\
& $\mathrm{~B}$ & 1.000 & 0.781 & 0.929 & 0.727 \\
LDH-2 & $\mathrm{A}$ & & 0.333 & 0.214 & 0.591 \\
& $\mathrm{~B}$ & 1.000 & 0.667 & 0.786 & 0.409 \\
MDH-1 & $\mathrm{A}$ & 0.100 & & & \\
& $\mathrm{~B}$ & 0.900 & 1.000 & 1.000 & 1.000 \\
MDH-2 & $\mathrm{A}$ & 0.950 & 0.857 & 0.889 & 0.786 \\
& $\mathrm{~B}$ & 0.050 & 0.143 & 0.111 & 0.214 \\
MPI & $\mathrm{A}$ & 0.458 & 0.083 & 0.143 & \\
& $\mathrm{~B}$ & 0.250 & 0.361 & 0.286 & \\
& $\mathrm{C}$ & 0.208 & 0.528 & 0.429 & 0.333 \\
& $\mathrm{D}$ & 0.084 & 0.028 & 0.143 & 0.667 \\
PEP-C2 & $\mathrm{A}$ & & 0.053 & & \\
& $\mathrm{~B}$ & 1.000 & 0.947 & 1.000 & 1.000 \\
PGM-2 & $\mathrm{A}$ & & 0.938 & & 0.950 \\
& $\mathrm{~B}$ & 1.000 & 0.062 & 1.000 & 0.050 \\
\hline & & & & &
\end{tabular}

Table 5. Nei's (1978) unbiased genetic distance below the diagonal, and $\mathrm{F}_{\mathrm{ST}}$ (bold) and $\mathrm{N}_{\mathrm{EM}}$ (italic) values above the diagonal.

\begin{tabular}{lllll}
\hline Population & Type 1 & Type 2 & Type 3 & Subtype 3 \\
\hline & & $\mathbf{0 . 1 1 9}$ & $\mathbf{0 . 0 7 0}$ & $\mathbf{0 . 1 5 1}$ \\
Type 1 & - & 1.041 & 1.868 & 0.791 \\
& & & $\mathbf{0 . 1 3 1}$ & $\mathbf{0 . 0 9 9}$ \\
Type 2 & 0.026 & - & 0.925 & 1.280 \\
& & & & $\mathbf{0 . 0 7 3}$ \\
Type 3 & 0.008 & 0.022 & - & 1.786 \\
Subtype 3 & 0.028 & 0.017 & 0.006 & - \\
\hline
\end{tabular}

(Table 5). These values are the smallest between Type 3 and Subtype 3, and this grouping occurred in all trees. However, the 35 positions of Type 1 and Type 2 interchange as sister groups. Average weighted fixation index values of the subpopulations relative to the total $\left(\mathrm{F}_{\mathrm{ST}}\right)$ range from moderate $(0.070-0.099)$ between 
Types 2, 3 and Subtype 3, to great (0.151) between the geographically most distant wave types (Type 1 and Subtype 3). The effective number of alleles exchanged between generations $\left(\mathrm{N}_{\mathrm{EM}}\right)$ values (Table 5) are larger (average $=1.33$ ) between the adjacent Types 2, 3 and Subtype 3 compared to Type 1 and the abovementioned individuals (average $=1.23$ ). Significant $(\mathrm{P}<0.05)$ differences between all of the wave types, except between Type 3 and Subtype 3, were calculated using pair-wise comparison of contingency Chi-square analysis. Differences $(\mathrm{P}<0.05)$ between Types 1 and 2 occurred at nine (EST-1,-2, GPI-1,-2, IDH, LDH-1,-2, MDH-1 and MPI), three (GPI-2, LDH-1 and -2), eight (EST-1,-2, GPI-1,-2, LDH-1,-2, MDH-2 and MPI), one (GPI-1), three (GPI-1, LDH-2 and MDH-2) and one (LDH-2) loci between Types 1 and 2, 1 and 3, 1 and Subtype 3, 2 and 3, 2 and Subtype 3 and 3 and Subtype 3 , respectively.

\section{DNA study}

Two data sets were available for analysis: Data set 1 consisted of 8 dwarf stonebashers from the Okavango System and 13 from the Kwando-Zambezi River System. For this data set sequence data of 1067 nucleotides each were available for analysis. Data set 2 consisted of 21 dwarf stonebashers including one specimen from Okavango, six specimens from the Kwando River, six specimens from the Zambezi River, and eight specimens from the Linyanti Swamps. All of the latter displayed EODs of the Kwando/Linyanti type, Type 2, whereas the EODs of the six Zambezi specimens were of Type $3(\mathrm{~N}=1)$ and Subtype $3(\mathrm{~N}=4)$. Data set 2 consisted of only 750 nucleotides.

The phylogenetic relationships of 21 dwarf stonebashers and one other mormyrid fish (Marcusenius macrolepidotus as outgroup) (data set 1) were reconstructed employing ML, MP and NJ (Figure 7). The tree topology in these three different reconstructions is quite similar: six dwarf stonebashers from the Okavango form a well supported monophylum (bootstrap value 100\%) which clusters as a sister group to the dwarf stonebashers from the Zambezi-Kwando River System (here collectively termed $P$. marianne because of their genetic similarity). Also two dwarf stonebashers from Okavango (nos 22A and 21B) show the sequence observed in Zambezi-Kwando System fish (Table 6). We suggest that these two specimens must have immigrated into the Okavango River system recently (unfortunately, their EOD has not been recorded). Within Zambezi-Kwando fish some
Table 6. Parsimony informative characters in data set 1 (1067 nucleotides) for the $P$. castelnaui species complex. Suffixes to specimen designations code for their origin: ok - Okavango River; za - Zambezi River; K - Kwando/Linyanti System. Outgroup: M. macrolepidotus.

\begin{tabular}{ll}
\hline Taxon/Node & \\
& 1222345677777788999999900 \\
& 9789333800013522001145512 \\
& 3105702206952139174965837 \\
\hline M. macrolepidotus & ACGCCCAT ACCATACACCCACTTAC \\
$P$. castelnaui.ok.25B & GCGTGGACCCTACGTGACTGTGTAC \\
$P$. castelnaui.ok.24A & GCGTGAACCCTACGTGACTGTGTAC \\
$P$. castelnaui.ok.24B & GCGTGAACCTTGTGTGACTGTGTAC \\
$P$. castelnaui.ok.22B & GCGTGAACCCTGCGTGACTGTGTAC \\
$P$. castelnaui.ok.22C & GCGTGAACCCTGCGTGACTGTGTAC \\
$P$. castelnaui.ok.22D & GCGTGAACCCTGCGTGACTGTGTAC \\
$P$. marianne.ok.21B & ACACAGGTACCACGCAGTCATACGT \\
$P$. marianne.ok.22A & ACACAGGTACCACGCAGTCATACGT \\
$P$. marianne.K39 & ATACAGGTACCACGCAGTCATACGT \\
$P$. marianne.K44 & ACACGGATACCACGCAGTCGTACAC \\
$P$. marianne.K14 & ACATGGGTACCACGCAGTCGTACAC \\
$P$. marianne.K45 & ACACAGGTACCACGCAGTCACACGT \\
$P$. marianne.K45 & ACACAGGTACCACGCAGTCATACGT \\
$P$. marianne.K46 & ACACGGGTANCACGCAGTCATACGT \\
$P$. marianne.K46 & ATACAGGTACCACGCAGTCATACGT \\
$P$. marianne.K47A & ACACAGGTACCACGCAGTCATACGT \\
$P$. marianne.K47B & ACACAGGTATCACGCAGTCATACGT \\
$P$. marianne.za.55B & ACACAGGTACCGCGCAGTCATACGT \\
$P$. marianne.za.55A & ACACAGGTACCACGCAGTCATACGT \\
$P$. marianne.za.53B & ACACAGGTACCGCGCAGTCATACGT \\
$P$. marianne.za.53A & ACACGGGTACCACACAGTCGTACAC \\
\hline & \\
\hline
\end{tabular}

phylogeographic differentiation can be seen, but it is not supported by significant bootstrap values. Genetic distances between $P$. castelnaui and Zambezi-Kwando fish are between $1.5 \%$ and $2.5 \%$.

For a further analysis we have combined data sets 1 and 2 and have analysed those 750 nucleotide positions which were determined for all individuals. Results of these analyses (only an MP tree is shown in Figure 8) confirm the first analysis: $P$. castelnaui is clearly separated from dwarf stonebashers sampled from the Kwando-Linyanti-Zambezi System. Within the latter clade intrageneric distances vary between $0.4-0.7 \%$; Table 7).

\section{Discussion}

\section{EOD and morphology}

Without exception for a large sample size, EOD waveforms differ categorically between $P$. castelnaui from 


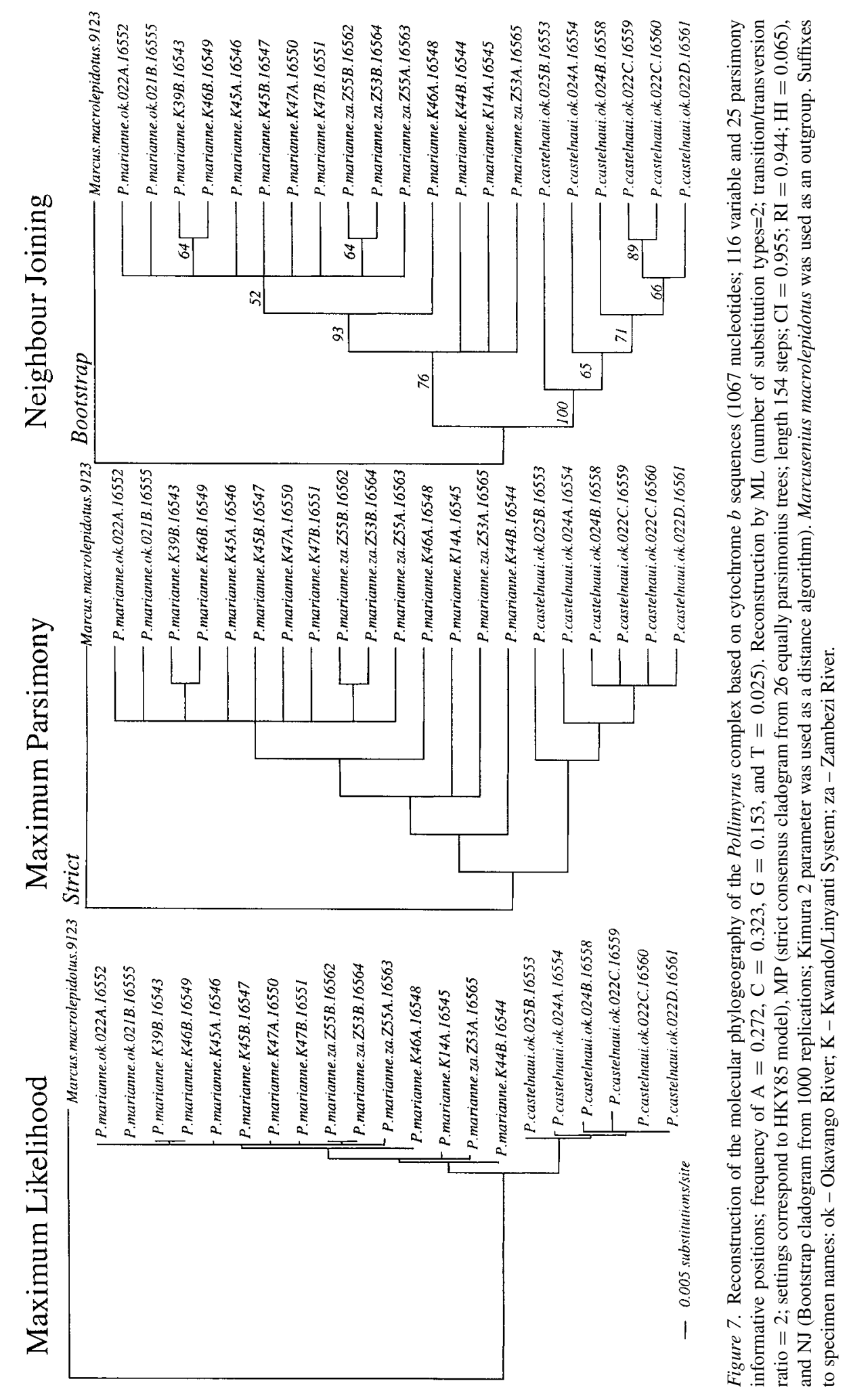




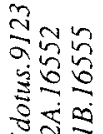



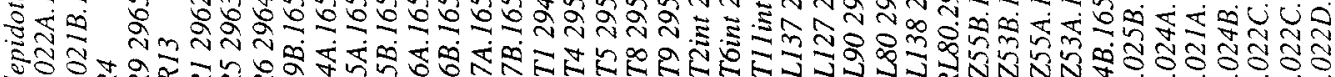

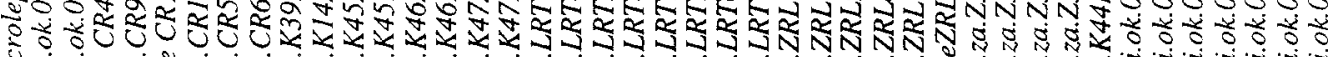

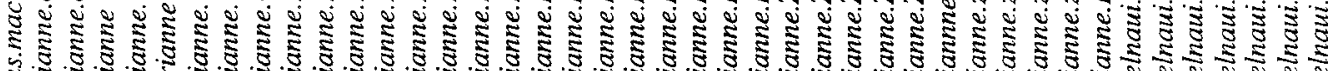

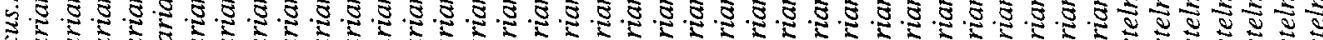
प气
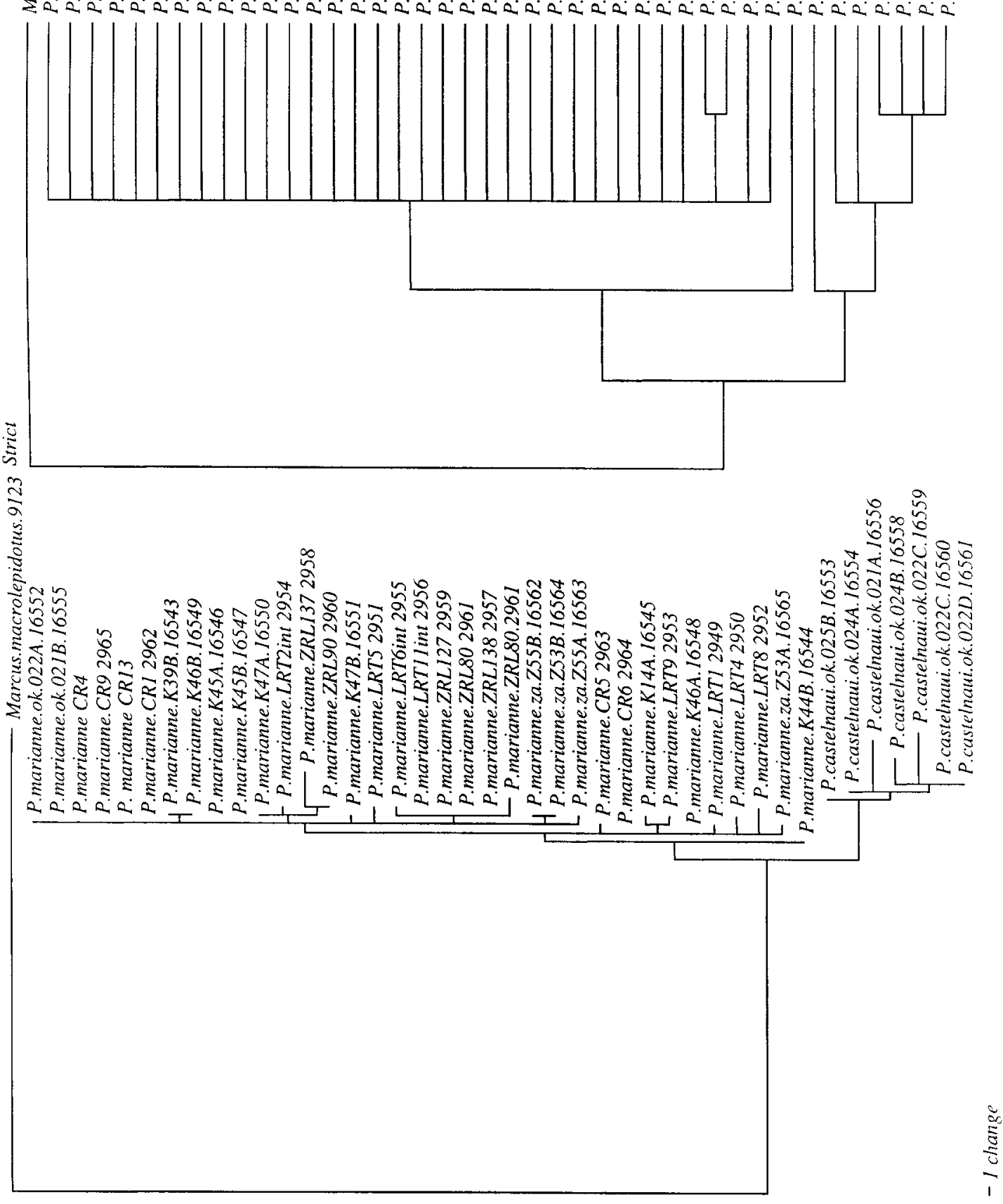
Table 7. Genetic distances between members of the P. castelnaui species complex. Suffixes to specimen designations code for their origin: ok - Okavango River; za - Zambezi River; K - Kwando/Linyanti System. Outgroup: M. macrolepidotus.

\begin{tabular}{|c|c|c|c|c|c|c|c|c|}
\hline \multicolumn{9}{|c|}{ Uncorrected ('p') distance matrix } \\
\hline & & 13 & 65 & 66 & 70 & 71 & 72 & 73 \\
\hline 13 & M. macrolepidotus & - & & & & & & \\
\hline 65 & P. castelnaui.ok. & 0.13182 & - & & & & & \\
\hline 66 & P. castelnaui.ok. & 0.13172 & 0.00196 & - & & & & \\
\hline 70 & P. castelnaui.ok. & 0.13420 & 0.00505 & 0.00505 & - & & & \\
\hline 71 & P. castelnaui.ok. & 0.14239 & 0.01205 & 0.01206 & 0.01226 & - & & \\
\hline 72 & P. castelnaui.ok. & 0.13606 & 0.00206 & 0.00206 & 0.00310 & 0.00625 & - & \\
\hline 73 & P. castelnaui.ok. & 0.13285 & 0.00192 & 0.00196 & 0.00303 & 0.01005 & 0.00000 & - \\
\hline 81 & P. marianne.K39 & 0.13079 & 0.01918 & 0.02161 & 0.02422 & 0.03216 & 0.02163 & 0.02109 \\
\hline 82 & P. marianne.K44 & 0.12784 & 0.01342 & 0.01573 & 0.01818 & 0.02613 & 0.01546 & 0.01536 \\
\hline 83 & P. marianne.K14 & 0.12976 & 0.01437 & 0.01670 & 0.01917 & 0.02711 & 0.01648 & 0.01630 \\
\hline 84 & P. marianne.K45 & 0.12873 & 0.01918 & 0.02161 & 0.02422 & 0.03216 & 0.02163 & 0.02109 \\
\hline 85 & P. marianne.K45 & 0.12976 & 0.01820 & 0.02063 & 0.02321 & 0.03112 & 0.02060 & 0.02013 \\
\hline 86 & P. marianne.K46 & 0.13057 & 0.01734 & 0.01976 & 0.02132 & 0.03030 & 0.01969 & 0.01929 \\
\hline 87 & P. marianne.K46 & 0.13079 & 0.01916 & 0.02161 & 0.02422 & 0.03213 & 0.02163 & 0.02109 \\
\hline 88 & P. marianne.K47 & 0.13120 & 0.01921 & 0.02167 & 0.02429 & 0.03223 & 0.02169 & 0.02115 \\
\hline 89 & P. marianne.K47 & 0.13079 & 0.01916 & 0.02161 & 0.02220 & 0.03213 & 0.02163 & 0.02109 \\
\hline 104 & P. marianne.za. & 0.13079 & 0.01918 & 0.02161 & 0.02220 & 0.03015 & 0.01957 & 0.01918 \\
\hline 105 & P. marianne.za. & 0.13141 & 0.02090 & 0.02191 & 0.02424 & 0.03223 & 0.02165 & 0.02191 \\
\hline 106 & P. marianne.za. & 0.13093 & 0.01919 & 0.02163 & 0.02222 & 0.03015 & 0.01957 & 0.01919 \\
\hline 107 & P. marianne.za. & 0.12784 & 0.01536 & 0.01770 & 0.02020 & 0.02814 & 0.01751 & 0.01727 \\
\hline \multicolumn{9}{|c|}{ Uncorrected ('p') distance matrix (continued) } \\
\hline & & 81 & 82 & 83 & 84 & 85 & 86 & 87 \\
\hline 81 & P. marianne.K39 & - & & & & & & \\
\hline 82 & P. marianne.K44 & 0.00576 & - & & & & & \\
\hline 83 & P. marianne.K14 & 0.00671 & 0.00288 & - & & & & \\
\hline 84 & P. marianne.K45 & 0.00192 & 0.00576 & 0.00671 & - & & & \\
\hline 85 & P. marianne.K45 & 0.00096 & 0.00479 & 0.00575 & 0.00096 & - & & \\
\hline 86 & P. marianne.K46 & 0.00193 & 0.00386 & 0.00482 & 0.00193 & 0.00096 & - & \\
\hline 87 & P. marianne.K46 & 0.00000 & 0.00575 & 0.00670 & 0.00192 & 0.00096 & 0.00193 & - \\
\hline 88 & P. marianne.K47 & 0.00192 & 0.00577 & 0.00672 & 0.00192 & 0.00096 & 0.00193 & 0.00192 \\
\hline 89 & P. marianne.K47 & 0.00192 & 0.00575 & 0.00670 & 0.00192 & 0.00096 & 0.00096 & 0.00192 \\
\hline 104 & P. marianne.za. & 0.00192 & 0.00576 & 0.00671 & 0.00192 & 0.00096 & 0.00193 & 0.00192 \\
\hline 105 & P. marianne.za. & 0.00199 & 0.00697 & 0.00796 & 0.00199 & 0.00199 & 0.00300 & 0.00299 \\
\hline 106 & P. marianne.za. & 0.00192 & 0.00576 & 0.00672 & 0.00192 & 0.00096 & 0.00193 & 0.00192 \\
\hline 107 & P. marianne.za. & 0.00576 & 0.00192 & 0.00288 & 0.00576 & 0.00480 & 0.00386 & 0.00576 \\
\hline \multicolumn{9}{|c|}{ Uncorrected ('p') distance matrix (continued) } \\
\hline & & 88 & 89 & 104 & 105 & 106 & 107 & \\
\hline 88 & P. marianne.K47 & - & & & & & & \\
\hline 89 & P. marianne.K47 & 0.00192 & - & & & & & \\
\hline 104 & P. marianne.za. & 0.00192 & 0.00192 & - & & & & \\
\hline 105 & P. marianne.za. & 0.00299 & 0.00299 & 0.00199 & - & & & \\
\hline 106 & P. marianne.za. & 0.00192 & 0.00192 & 0.00000 & 0.00199 & - & & \\
\hline 107 & P. marianne.za. & 0.00577 & 0.00576 & 0.00576 & 0.00598 & 0.00576 & - & \\
\hline
\end{tabular}

the Okavango and P. marianne from the Upper Zambezi River (Figure 4). Also morphologically, samples from the two populations differ significantly in 13 out of 14 characters studied (multivariate analysis of Table 3 ). Therefore, species status is recognised for P. marianne from the Zambezi River (see confirmation by DNA results, below).

EOD and morphology comparisons also revealed that the geographically intermediate Kwando/Linyanti System holds a third phenotype within the Pollimyrus 
complex. Morphologically and especially electrically, contrasts with the two neighbouring populations appear greater for the Zambezi River than for the Okavango populations, despite the association of the Kwando/Linyanti System with the Upper Zambezi River. The Kwando/Linyanti population shows more within-group variability than the other two species, including aspects of a clinal variation (more similarity with the Zambezi River population the closer one gets). However, Kwando fish cannot be clearly differentiated from Linyanti fish, consistent with the continuity of these two sections of a single river. The relatively high intra-group variability of EOD waveforms and some morphological characters (such as $\mathrm{SPc}$ ), is rather unusual in mormyrid species. This could be evidence for an only recently evolved species status for the Kwando/Linyanti population, with electrical and also some morphological contrasts (character displacement) perhaps still forming against the Zambezi River population.

Thus, the Okavango-Upper Zambezi region holds three distinct, morphologically and electrically defined taxa for what has traditionally been considered a single species, $P$. castelnaui. All three taxa are clearly diagnosable by morphological and electrical characters. The three taxa do not overlap in geographical range, except for a few specimens displaying a Type 3 EOD waveform that were sampled in the Kwando/Linyanti System (in numbers decreasing with distance from the Zambezi River). Immigration of Zambezi individuals into the Kwando/Linyanti System (via Chobe and/or Lake Liambezi) is the most likely explanation when taking the recent flooding history into account (see Materials and methods).

\section{Allozymes}

An allozyme study estimated the genetic difference between the above-mentioned, local EOD wave types. There are indications of hybridisation in gene frequency distributions (e.g., intermediate in the frequencies of the MPI*B, LDH-1*A,-2*A, MDH-2*B and $\mathrm{IDH}^{*} \mathrm{C}$ alleles in Type 2 individuals) and/or clinal variation (i.e., a decrease in the MPI*D alleles from Type 1 to Subtype 3 individuals) (Table 4). When the $\mathrm{D}_{78}$ values are compared to results obtained by other authors with respect to conspecific populations and/or congeneric species, it is evident that the genetic distances of the present study are within an intra-specific range. For example, Shaklee et al. (1982) found that the
$D$ value between pairs of species in fish from the same genus ranged from 0.03 to 0.61 (average $=0.3$ ) and Thorpe (1982) and Thorpe \& Solé-Cava (1994) also recommended a value of 0.3 for conspecific populations. Our values are more than a factor lower $(<0.03$, Table 5) than the above-mentioned value, although the value between Subtype 3 and Type 1 (0.028) is close to Shaklee's lower limit.

Variable relationships were produced from $\mathrm{D}_{78}$ values, except for the constant grouping of Type 3 with Subtype 3 individuals. Nevertheless, we have obtained an association between geographic distance and genetic distance; the $\mathrm{D}_{78}$ values (Table 5) were the largest between Type 1 and Subtype 3 and the smallest between Type 3 and Subtype 3 (Zambezi) fish. It is not evident why a small genetic distance $(0.008)$ and $\mathbf{F}_{\mathrm{ST}}(0.070)$, and the largest $\mathrm{N}_{\mathrm{EM}}(1.868)$ values were obtained between Types 1 and 3 . This could be due to small sample sizes analysed.

Wright's (1978) fixation (F) index, or inbreeding coefficient, is another measure of divergence and it gives an indication of the chance that a gamete will unite with an identical gamete. This is brought about by the tendency for the accumulation in the population of the genes that are able to confer even minute selective advantages (Mayr 1970) by a process termed 'random fixation'. As time proceeds, the value of $\mathrm{F}$ becomes larger as the homozygosity of the population increases due to inbreeding, despite selection in favour of heterozygotes (Mayr 1970, Cook 1991). The average weighted $\mathbf{F}_{\text {ST }}$ value for the EOD wave types is 0.107 , which is an indication of moderate differentiation. The pair-wise $\mathbf{F}_{\mathbf{S T}}$ value (0.151) between Type 1 and Subtype 3 is the largest and indicates great differentiation. In the event of subspecies, the within-population component of genetic variation will be much smaller than the between-population component (Nei 1973). The gene diversity analysis in the present study revealed that $84.9-93 \%$ of the total diversity originated from diversity within wave types, and only $7-15.1 \%$ between types. There is a lack of fixed allele differences between the wave types (Table 4$)$, but significant $(\mathrm{P}<0.05)$ differences between waveforms (except between Type 3 and Subtype 3) were determined using pair-wise comparison of contingency Chi-square analysis. The significant $(\mathrm{P}<0.001)$ differences between Type 1 and all the other groups are once again congruent with conclusions from EOD and morphological data. These differences indicate microevolution (significant differences) between Upper Zambezi River System wave types and the Okavango individuals. In addition, the 
clinal and intermediate distribution of some alleles might indicate hybridisation or simply the presence of mixed gene pools, as can be expected when the river systems link.

Microevolution is dependent on changes that result from the action of natural selection on individuals (Cockburn 1991) that, in any way, promotes the differential perpetuation of certain genotypes (Mayr 1970). Speciation, although it proceeds faster in freshwater systems (Mayr 1970), is a timely process and is still a function of population size and dependent on the degree of reproductive isolation between the populations. The interaction between these diverse processes and other factors have already resulted in a small degree of genetic divergence (as detected by allozymes) between the wave types studied, and may result in the appearance of a new sub-species, if not a new species, with the passage of time.

\section{$D N A$}

All fish from the Upper Zambezi River System combined, that is, including the Kwando/Linyanti System, form one well-supported sister clade, $P$. marianne, to $P$. castelnaui from the Okavango which is in a basal position (with the exception of two odd Okavango individuals, see Results). All other individuals are derived from this basal clade. Genetic distances between P. castelnaui and the combined Zambezi-Kwando System fish are between 1.5 and $2.5 \%$, indicating that both taxa must have separated some time ago. Assuming a molecular clock of about $2 \%$ sequence divergence for mitochondrial genes in 1 million years (Wilson et al. 1987), such a separation might have taken place about 1 million years ago.

Some phylogeographic differentiation is seen within samples from the Upper Zambezi River System, and genetic distances vary from $0.4-0.7 \%$. Zambezi River and Linyanti Swamp individuals are segregated to some degree, whereas Kwando River individuals do not seem to follow any recognisable pattern. This implies that the dwarf stonebashers from the Kwando River and the Linyanti/Zambezi System have already been separated for some time. According to the above-mentioned molecular clock a divergence time of 200 000-300 000 years would result. Since the molecular clock is usually enhanced in species with high reproduction rates and short generation times, an even shorter time period would be more likely, thus 50 000-100 000 years would be a plausible assumption for the divergence within the $P$. marianne clade. Despite the finding that morphology and EOD patterns are already quite distinct, speciation must have taken place rather recently in this species complex.

The Kwando/Linyanti fish show the genetic sequence characteristic for $P$. marianne, in spite of their clear morphological distance from the Zambezi River population, and EODs more similar to (but clearly distinct from, see Figure 5) those of P. castelnaui.

\section{Conclusions}

EOD, morphology and mitochondrial DNA results all recognise a sister species to $P$. castelnaui, $P$. marianne, inhabiting the Zambezi River. According to the mitochondrial DNA results fish from the Kwando/Linyanti System would belong to the new species. However, the allozyme results do not support any species barrier among the fish studied because genetic distances measured in this way are far below what has often been considered the typical value for a species difference. The lack of fixed allele differences would also suggest intra-population variability. Nevertheless, great genetic differentiation in terms of $\mathbf{F}_{\mathrm{ST}}$ values and contingency Chi-square analyses revealed that the Okavango (Type 1) and the other groups are more distant compared to the relationships amongst the latter group.

This conflict between two different genetic methods with different strengths is not new. The DNA method is likely to give better resolution when synonymous substitutions that are not detected by allozyme techniques are numerous. Non-synonymous substitutions tend to be more rare, and we consider the DNA evidence in favour of $P$. marianne very strong.

A second reason for divergence of results (among genetic techniques and also when compared to other techniques, such as morphology) is that gene trees and species trees have often been found to differ considerably (the reasons are discussed in Futuyma 1998, chapter 15). A third reason is that the assumption of sizable genetic differences being required for a species difference to exist has been found not to be true especially for many sympatric species. In a recent key paper on fish species, Turner (1999) concludes that 'genetic distinctness is not a good guide to whether populations are species or not', citing examples such as allozyme studies that have shown that the entire Malawian and Victorian radiations of cichlid fishes, about 1500 species, are about as genetically diversified as a 
pair of subspecies of North American fishes (Kornfield 1978; Verheyen \& Van Rompaey 1986).

According to Turner (1999), mitochondrial DNA studies have given a similar picture. For example, in spite of considerable ecological and morphological diversity in the more than 400 species of cichlid fishes of Lake Victoria, genetic variation among these species is less than in the single species, Homo sapiens (Meyer et al. 1990; see also Stiassny \& Meyer 1999). Molecular clocks that are roughly calibrated on mutations of mitochondrial genes indicate that this entire assemblage of species evolved within the past 200000 years (and possibly many species in less than 14000 years as suggested by certain paleoclimatological data). Carvalho \& Hauser (1999) agree with Turner: 'While genetic distances are not always a good guide for species classification, they do reflect the young age of these species flocks.' They also state that 'It is therefore inappropriate to assume that molecular markers can provide the final answer to species identification; they are instead an additional marker system, which can be used to increase the resolution in taxonomic research ...'. As a reason these authors quote 'the neutrality of most molecular markers to selective forces [so that] their ability to distinguish recently diverged taxa [is limited], whereas adaptive traits, such as morphological or meristic characters used in taxonomy, are under natural selection and thus may diverge faster'.

EODs, these fishes' prime communication signal, are certainly also under natural selection, as demonstrated by the astounding diversity among species, and a sexual dimorphism in EOD waveform in M. macrolepidotus (Kramer 1997a,b). Therefore, we recognise $P$. marianne as a valid new species in spite of little genetic allozyme differentiation from $P$. castelnaui detected so far.

The DNA results clearly show that $P$. castelnaui is the basal clade in the Pollimyrus complex from which all other individuals of our study are derived. When going from west to east, it is interesting to note how the complexity of EOD waveform in this species (five phases in the Okavango) is gradually transformed, becoming different and more variable in the Kwando System, and finally reduced to only three phases in $P$. marianne in the Zambezi River. A minority of Zambezi River individuals still show what appears to be a small historical remnant of this complexity (Subtype 3 EODs).

Kwando/Linyanti fish share common ancestry with Zambezi River fish and are mutually their closest relatives, as clearly demonstrated by an identical characteristic sequence of mitochondrial DNA (Table 6). Despite some phylogeographic variation (Figures 7 and 8), Kwando/Linyanti fish cannot be differentiated clearly from Zambezi River fish either by DNA or by allozyme methods. For the past six decades at least, the Kwando System has represented more of an inland system rather than a tributary, falling short of reaching the Zambezi River (except during brief and rare periods of flooding by the Zambezi River). The semi-isolated Kwando System population was probably influenced by immigration/hybridization from both sides, the Zambezi River and the Okavango River (see Geography in Materials and methods). Flooding by the Zambezi River has probably been more important for the terminal Kwando System than the tenuous link of the Kwando with the Okavango River (the Zambezi having also other, far more copious sources than only those in the Angolan highlands of Bié which feed the Okavango and the Kwando). Therefore, the Kwando/Linyanti fish have come into contact with Zambezi River fish fairly regularly during periods of high flood, and, apparently, an evolution of contrast by character displacement has taken place against the closer kin. This resulted in Kwando/Linyanti fish being more distinct in EOD and morphology from their Zambezi River relatives than from their more distant Okavango relatives. Today, Kwando/Linyanti fish might be reproductively isolated from both Zambezi River and Okavango fish, as suggested by the sophisticated EOD recognition mechanisms of mormyrid species (Graff \& Kramer 1992, Paintner 1998, Paintner \& Kramer in preparation). Their unique combination of EOD and morphological characters sets them sufficiently apart from both neighbouring species to support this assumption.

\section{Acknowledgments}

We thank James MacLaine and Anthony Gill (BMNH) for the loan of type specimens; Paul Skelton and Roger Bills (South African Institute for Aquatic Biodiversity (formerly the JLB Smith Institute of Ichthyology), Grahamstown, SA), for catching and sending three live specimens from the Okavango, and the loan of SAIAB museum specimens from the Okavango; Peter Ashton (CSIR - Environmentek, Pretoria), for ecology data from the Okavango sampling site; Klaus Heine (Geography Department, Univ. of Regensburg) 
for help with and final production of Figure 3; Kathrin Kahler, for anatomical measurements and Figure 2; and Stefan Buchhauser, for the photographic work in Figure 1.

\section{References cited}

Alves-Gomes, J. \& C.D. Hopkins. 1997. Molecular insights into the phylogeny of Mormyriform fishes and the evolution of their electric organs. Brain Behav. Evol. 49: 324-351.

Bass, A.H. 1986. Electric organs revisited: evolution of a vertebrate communication and orientation organ. pp. 13-70. In T.H. Bullock \& W. Heiligenberg (ed.) Electroreception, John Wiley, New York.

Bennett, M.V.L. 1971. Electric organs. pp. 347-491. In: W.S. Hoar \& D.J. Randall (ed.) Fish Physiology, Vol 5, Academic Press, New York.

Bell-Cross, G. \& J.L. Minshull. 1988. The fishes of Zimbabwe. Harare: National Museums and Monuments of Zimbabwe. $294 \mathrm{pp}$.

Boulenger, G.A. 1911. On a collection of fishes from the Lake Ngami basin. Trans. Zool. Soc. 18: 399-430.

Bratton, B.O. \& B. Kramer. 1988. Intraspecific variability of the pulse-type discharges of the African electric fishes, Pollimyrus isidori and Petrocephalus bovei (Mormyridae, Teleostei) and their dependence on water conductivity. Exp. Biol. 47: 227-238.

Bratton, B.O. \& B. Kramer. 1989. Patterns of the electric organ discharge during courtship and spawning in the mormyrid Pollimyrus isidori. Behav. Ecol. Sociobiol. 24: 349-368.

Carvalho, G.R. \& L. Hauser. 1999. Molecular markers and the species concept: New techniques to resolve old disputes? Rev. Fish Biol. Fish. 9: 379-382.

Cockburn, A. 1991. An Introduction to Evolutionary Ecology. Blackwell Scientific Publications, London. 370 pp.

Cook, L.M. 1991. Genetic and Ecological Diversity: The Sport of Nature. Chapman \& Hall, London. 208 pp.

Crawford, J.D. 1991. Sex recognition by electric cues in a soundproducing mormyrid fish, Pollimyrus isidori. Brain Behav Evol. 38: 20-38.

Desjardins, P. \& R. Morais. 1990. Sequence and gene organisation of chicken mitochondrial genome. J. Mol. Biol. 212: 599-634

Futuyma, D.J. 1998. Evolutionary Biology 3rd edn. Sinauer, Sunderland. $763 \mathrm{pp}$.

Gosse, J.-P. 1984. Mormyriformes. pp. 63-124. In: J. Daget, J.-P. Gosse, \& D.F.E. Thys van den Audenaerde (ed.) Check-list of the Freshwater Fishes of Africa, Vol 1, ORSTOM/MRAC, Bondy (France)/Tervuren (Belgium).

Graff, C. \& B. Kramer. 1992. Trained weakly-electric fishes Pollimyrus isidori and Gnathonemus petersii (Mormyridae, Teleostei) discriminate between waveforms of electric pulse discharges. Ethology 90: 279-292.

Grobler, H.J.W. 1987. 'n Visekologiese studie van die Liambezimeer in Caprivi, Suidwes-Afrika. (A Fish-ecological Study on Lake Liambezi in Caprivi, South-West Africa). M.Sc. dissertation, Rand Afrikaans University, Auckland Park (South Africa). $139 \mathrm{pp}$.
Heidrich, P., C. König \& M. Wink. (1995). Bioakustik, Taxonomie und molekulare Systematik amerikanischer Sperlingskäuze (Strigidae: Glaucidium spp.). Stuttgarter Beiträge zur Naturkunde A, 534: 1-47.

Jubb, R.A. 1958. A preliminary report on the collections of freshwater fishes made by the Bernard Carp expeditions to the Caprivi Strip, 1949, the lower Sabi River, 1950, and to Barotseland, 1952. Occasional Papers of the National Museums of Southern Rhodesia 3(22b): 177-189.

Kocher, T.D. \& C.A. Stepien. 1997. Molecular Systematics of Fishes. Academic Press, San Diego. 520 pp.

Kocher, T.D., W.K. Thomas, A. Meyer, S.V. Edwards, S. Pääbo, F.X. Villablanca \& A.C. Wilson. 1989. Dynamics of mitochondrial DNA evolution in animals: Amplification and sequencing with conserved primers. Proc. Natl. Acad. Sci. USA 86: 6196-6200.

Kornfield, I. 1978. Evidence for rapid speciation in African cichlid fishes. Experientia 34: 335-336.

Kramer, B. 1990. Electrocommunication in Teleost Fishes: Behavior and Experiments. Springer-Verlag, Berlin. 240 pp.

Kramer, B. 1996. Electroreception and Communication in Fishes. Gustav Fischer Verlag, Stuttgart. 119 pp.

Kramer, B. 1997a. Electric organ discharges and their relation to sex in mormyrid fishes. Naturwissenschaften 84: 119-121.

Kramer, B. 1997b. A field study of African elephantfish (Mormyridae, Teleostei): electric organ discharges in Marcusenius macrolepidotus (Peters, 1852) and Petrocephalus catostoma (Günther, 1866) as related to sex. J. Afr. Zool. 111: 313-341.

Kramer, B. \& B. Kuhn. 1993. Electric signalling and impedance matching in a variable environment: the electric organ of a mormyrid fish actively adapts to changes in water conductivity. Naturwissenschaften 80: 43-46.

Kramer, B. \& F.H. Van der Bank. 2000. The southern churchill (Petrocephalus wesselsi), a new species of mormyrid from South Africa defined by electric organ discharges, genetics, and morphology. Environ. Biol. Fishes 59: 393-413.

Kramer, B., F.H. Van der Bank \& M. Wink. 2003. Hippopotamyrus ansorgii species complex in the Upper Zambezi River System with a description of a new species, H. szaboi (Mormyridae). Zool. Scripta 32: in press.

Kramer, B. \& G.W.M. Westby. 1985. No sex difference in the waveform of the pulse type electric fish, Gnathonemus petersii (Mormyridae). Experientia 41: 1530-1531.

Lavoué, S., R. Bigorne, G. Lecointre, \& J.-F. Agnèse. 2000. Phylogenetic relationships of mormyrid electric fishes (Mormyridae; Teleostei) inferred from cytochrome $b$ sequences. Mol. Phylogenet. Evol. 14: 1-10.

Leviton, A.E., R.H. Gibbs, E. Heal, \& C.E. Dawson 1985. Standards in herpetology and ichthyology: part I. Standard symbolic codes for institutional resource collections in herpetology and ichthyology. Copeia 1985: 802-832.

Lissmann, H.W. 1958. On the function and evolution of electric organs in fish. J. Exp. Biol. 35: 156-191.

Mayr, E. 1970. Populations, Species, and Evolution: An Abridgement of Animal Species and Evolution. Belknap Press, Boston. 453 pp.

Meyer, A., D.T. Kocher, P. Basasibwaki \& A.C. Wilson. 1990. Monophyletic origin of Lake Victoria cichlid fishes 
suggested by mitochondrial DNA sequences. Nature 347: 550-553.

Moller, P. 1995. Electric Fishes: History and Behavior. Chapman \& Hall, London. 584 pp.

Nei, M. 1973. Analysis of gene diversity in subdivided populations. Proc. Natl. Acad. Sci. USA. 70: 3321-3323.

Nei, M. 1978. Estimation of average heterozygosity and genetic distance from a small number of individuals. Genetics 89: 583-590.

Pääbo, S. 1990. Amplifying ancient DNA. pp. 159-166. In: M.A. Innes, D.H. Gelfand, J.J. Sninsky \& T.J. White (ed.). PCR Protocols: A Guide to Methods and Applications, Academic Press, San Diego.

Paintner, S. (1998) Elektrosensorische Grundlagen der Impulskurvenformanalyse für die Individualerkennung bei Pollimyrus adspersus (Mormyridae, Teleostei). Ph.D. Dissertation, University of Regensburg.

Paintner, S. \& B. Kramer. In preparation. Electrosensory basis for individual recognition in a weakly electric, mormyrid fish, Pollimyrus adspersus (Günther, 1866).

Schlettwein, C.H.G. 1985a. Third annual report on the hydrology of the Eastern Caprivi. Unpublished Report. Department of Water Affairs, South-West Africa. 27 pp.

Schlettwein, C.H.G. 1985b. The biological control of Salvinia molesta. Unpublished Report. Department of Water Affairs, South-West Africa. 19 pp.

Shaklee, J.B., C.S. Tamaru \& R.S. Waples. 1982. Speciation and evolution of marine fishes studied by electrophoretic analysis of proteins. Pac. Sci. 36: 141-157.

Skelton, P.H. 2001. A complete guide to the freshwater fishes of southern Africa. 2nd edn. Struik Publishers, Cape Town. 395 pp. (1st edn. 1993).

Skelton, P.H., M.N. Bruton, G.S. Merron \& B.C.W. van der Waal. 1985. The fishes of the Okavango drainage system in Angola, South West Africa and Botswana: taxonomy and distribution. Ichthyol. Bull. J.L.B.Smith Inst. Ichthyol. 50: 1-21.

Stiassny, M.L.J. \& A. Meyer. 1999. Cichlids of the Rift Lakes. Sci. Am. 280(2): 44-49.

Sullivan, J.P., S. Lavoué \& C.D. Hopkins. 2000. Molecular systematics of the African electric fishes (Mormyroidea: Teleostei) and a model for the evolution of their electric organs. J. Exp. Biol. 203: 665-683.

Swofford, D.L. 2001. PAUP*. Phylogenetic analysis using parsimony (and other methods). Version 4.0b8. Sinauer Associates, Sunderland. (Software with user's manual, $257 \mathrm{pp}$ ).

Swofford, D.L., R.B. Selander \& W.C. Black. 1997. BIOSYS-2: A computer program for the analysis of allelic variation in genetics. Department of genetics and development. University of Illinois at Urbana-Champaign, Urbana, Illinois 60801, U.S.A. (Software with user's manual, $64 \mathrm{pp}$ ).
Szabo, T. 1974. Anatomy of the specialized lateral line organs of electroreception. pp. 13-58. In: A. Fessard (ed.) Handbook of Sensory Physiology, Vol III/3, Springer-Verlag, Berlin.

Szabo, T. \& A. Fessard. 1974. Physiology of electroreceptors. pp. 59-124. In: A. Fessard (ed.) Handbook of Sensory Physiology, Vol III/3, Springer-Verlag, Berlin, Heidelberg, New York.

Taverne, L. 1971. Ostéologie des genres Marcusenius Gill, Hippopotamyrus Pappenheim, Cyphomyrus Myers, Pollimyrus Taverne et Brienomyrus Taverne (Pisces Mormyriformes). Ann. Mus. R. Afr. Cent. Zool. 188: 1-144.

Thorpe, J.P. 1982. The molecular clock hypothesis: Biochemical evolution, genetic differentiation and systematics. Ann. Rev. Ecol. Syst. 13: 139-168.

Thorpe, J.P. \& A.M. Solé-Cava. 1994. The use of allozyme electrophoresis in invertebrate systematics. Zool. Scripta 23: 3-18.

Turner, G.F. 1999. What is a fish species? Rev. Fish Biol. Fish. 9: 281-297.

Turner, R.W., L. Maler \& M. Burrows (ed.). 1999. Electroreception and electrocommunication. J. Exp. Biol. 202: 1167-1458.

Van der Bank, F.H. 1996. Inter-and intraspecific allozyme comparisons of mormyrids (Pisces, Mormyridae) from South Africa and Namibia, with reference to an undescribed species. Water SA 22(3): 285-290.

Van der Bank, F.H. \& B. Kramer. 1996. Phylogenetic relationships between eight African species of mormyriform fish (Teleostei, Osteichthyes): Resolution of a cryptic species, and reinstatement of Cyphomyrus Myers, 1960. Biochem. Syst. Ecol. 24: 275-291.

Van der Bank, F.H. \& M. van der Bank. 1995. An estimate of the amount of genetic variation in the snoutfish Marcusenius macrolepidotus (Peters, 1852). Water SA 21: 265-268.

Van der Waal, B.C.W. 1978. 'n Visekologiese studie van die Liambezimeer in die Oos-Caprivi met verwysing na visontgunning deur die Bantoebevolking (A fish-ecological study of the Liambezi Lake in the Eastern Caprivi with reference to subsistance fishing by the native Bantu people). Ph.D. Dissertation, Rand Afrikaans University. 192 pp.

Van der Waal, B.C.W. \& P.H. Skelton. 1984. Check-list of fishes of Caprivi. Madoqua 13: 303-320.

Verheyen, E. \& J. van Rompaey. 1986. Genetics and speciation in African lacustrine cichlids. Ann. Mus. R. Afr. Centr. Zool. 251: 95-101.

Wilson, A.C., H. Ochmann \& E.M. Prager. 1987. Molecular time scale for evolution. Trends Genetics 3: 241-247.

Wright, S. 1978 . Evolution and the Genetics of Populations (Vol 4): Variability Within and Among Natural Populations. University of Chicago Press, Chicago. 590 pp. 